\title{
Papua New Guinea: 2006 Article IV Consultation-Staff Report; and Public Information Notice on the Executive Board Discussion for Papua New Guinea
}

Under Article IV of the IMF's Articles of Agreement, the IMF holds bilateral discussions with members, usually every year. In the context of the 2006 Article IV consultation with the Papua New Guinea, the following documents have been released and are included in this package:

- $\quad$ the staff report for the 2006 Article IV consultation, prepared by a staff team of the IMF, following discussions that ended on November 17, 2006, with the officials of Papua New Guinea on economic developments and policies. Based on information available at the time of these discussions, the staff report was completed on February 15, 2007. The views expressed in the staff report are those of the staff team and do not necessarily reflect the views of the Executive Board of the IMF; and

- a Public Information Notice (PIN) summarizing the views of the Executive Board as expressed during its March 7, 2007 discussion of the staff report that concluded the Article IV consultation.

The document listed below has been or will be separately released.

Selected Issues Paper and Statistical Appendix

The policy of publication of staff reports and other documents allows for the deletion of market-sensitive information.

To assist the IMF in evaluating the publication policy, reader comments are invited and may be sent by e-mail to publicationpolicy@imf.org.

\author{
Copies of this report are available to the public from \\ International Monetary Fund • Publication Services \\ $70019^{\text {th }}$ Street, N.W. • Washington, D.C. 20431 \\ Telephone: (202) 623-7430 • Telefax: (202) 623-7201 \\ E-mail: publications@imf.org • Internet: http://www.imf.org
}

Price: $\$ 18.00$ a copy

\section{International Monetary Fund \\ Washington, D.C.}



INTERNATIONAL MONETARY FUND

\title{
PAPUA NEW GUINEA
}

\section{Staff Report for the 2006 Article IV Consultation}

\author{
Prepared by Asia and Pacific Department \\ (In consultation with other departments)
}

Approved by Steven Dunaway and Adrienne Cheasty

February 15, 2007

- Discussions: Held in Port Moresby during November 6-17, 2006. The staff met with the Treasury Minister Namaliu, Central Bank Governor Kamit, and other senior officials, and representatives of donors, the private sector, and civil society.

- Team: Ms. Creane (head), Mr. Hussain, Ms. Mineshima (all APD), Mr. Chua (FAD), and Mr. Faal (Resident Representative). Mr. Murray (OED) joined the discussions. The team coordinated with the World Bank and the Asian Development Bank.

- $\quad$ Exchange system: Managed float. Papua New Guinea has accepted the obligations of Article VIII, Sections 2, 3, and 4, and maintains an exchange system free of restrictions on payments and transfers for current international transactions (Annex I).

- Previous Article IV consultation: The last Article IV consultation was concluded on February 13, 2006, and Directors' comments may be found at http://www.imf.org/external/np/sec/pn/2006/pn0620.htm.

- $\quad$ Economic statistics: Have improved (Annex V), but further strengthening in the quality and timing of national accounts, balance of payments, and government finance data is needed.

- Publication policy: The authorities indicated their intention to publish the staff report and background documents, as in the past. A press statement was issued by the Resident Representative office at the end of the consultation. 
Executive Summary 3

I. Introduction 4

II. Background .7

III. Policy Discussions ... .19

IV. Staff Appraisal .28

\section{Boxes}

1. Medium-Term Development Strategy ….........................................................

2. Role of the Mining Sector in Papua New Guinea.................................................. 15

3. Reserve Adequacy and Costs of Carrying Reserves, 1980-2005..........................21

4. Is Papua New Guinea Competitive? ..............................................................22

\section{Figures}

1. Progress Toward Selected Millennium Development Goals ....................................6

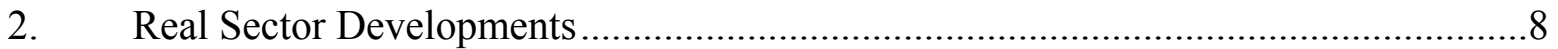

3. External Sector Developments..................................................................

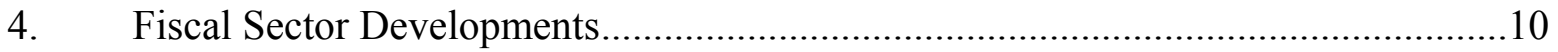

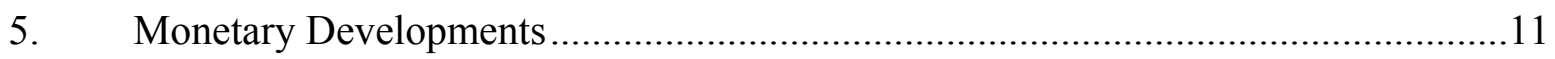

6. Regional and Global Comparators, 2004-06 ....................................................13

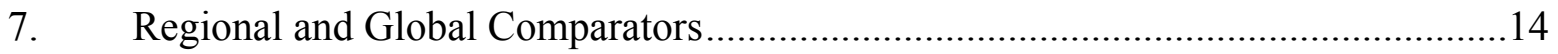

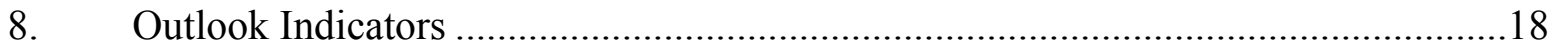

Tables

1. Millennium Development Goals Progress, 1990-2004 ........................................30

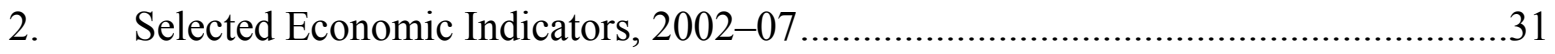

3. Summary of Central Government Operations, 2003-07 ......................................32

4. Summary Accounts of the Banking System, 2002-07 ...........................................33

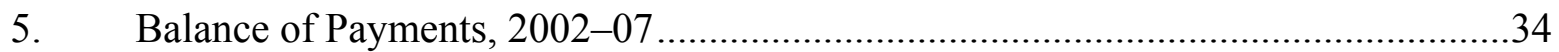

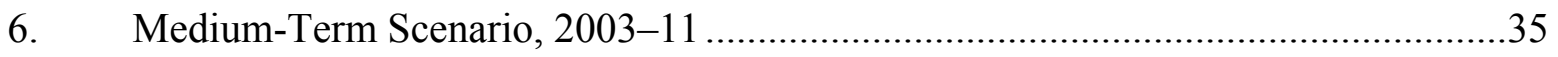

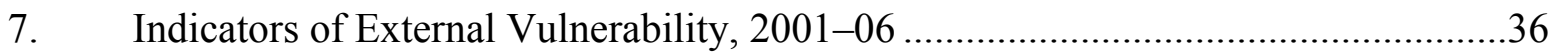

Appendices

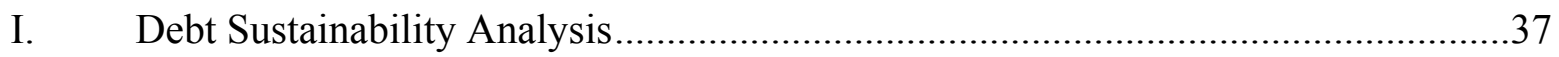

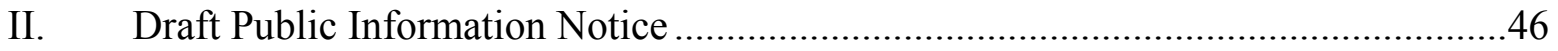

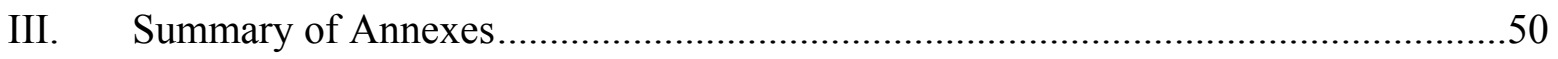




\section{EXECUTIVE SUMMARY}

- $\quad$ Papua New Guinea is enjoying its fourth year of recovery and macroeconomic stability, supported by broadly sound economic policies and record mineral revenue inflows. The current economic performance is strong relative to recent history.

- However, the performance gap relative to comparator countries is widening given higher growth among peers, while downside risks for Papua New Guinea have increased, and development needs remain high.

- The near-term challenge is to continue following an appropriate fiscal-monetary policy mix that maintains macroeconomic stability.

- $\quad$ Monetary policy should continue to maintain low inflation, and the authorities should stand ready to tighten the stance if fiscal-related demand pressures intensify.

- Given the expectation of diminished mineral revenue inflows, the current managed floating exchange rate appropriately allows a build-up of reserves while protecting nonmineral sector competitiveness by resisting rapid appreciation of the kina. However, greater flexibility would be needed in the face of sustained pressure.

- $\quad$ The 2006-07 budgets are appropriately focused on one-off development spending increases given the temporary nature of current record mineral revenue inflows. However, keeping in mind past election-related fiscal policy excesses, the authorities should take measures to minimize the potential for nonpriority expenditure and associated inflationary pressures emerging ahead of the mid-2007 general elections.

- A more ambitious medium-term fiscal strategy would better cope with volatile and exhaustible mineral revenue and anchor fiscal sustainability. The suggested strategy would use budget surpluses to pay down public debt while leaving room for more spending in areas that would contribute to higher sustained nonmineral sector growth.

- A key medium-term challenge is to renew momentum on structural reformsincluding in the public sector-to raise growth in the nonmineral sector and reduce unemployment and poverty.

- The investment environment needs considerable strengthening, including by addressing a poor communications and transportation infrastructure, high crime, and weak governance. 


\section{INTRODUCTION}

\section{Papua New Guinea is enjoying its fourth year of recovery and macroeconomic} stability, but major challenges lie ahead. Sound macroeconomic policies over the past several years have reduced fiscal vulnerabilities, lowered inflation, spurred business confidence, and boosted growth. High prices for key export commodities (petroleum, copper, and gold) have strengthened the fiscal and external positions. However, progress toward achieving the country's Medium-Term Development Strategy (MTDS) objectives or Millennium Development Goals (MDGs) has been limited (Box 1, Table 1, and Figure 1). In particular, structural reforms needed to stimulate activity in the nonmineral economy have stalled in advance of the June 2007 general elections.

\section{Reflecting past years of political instability and weak economic management,} per capita income is little improved since independence in 1975. As a result of earlier election-year fiscal policy excesses, the current government faced a near crisis situation when it took office in 2002; its efforts during its initial years mainly — and successfullyfocused on stabilizing the fiscal situation and promoting economic recovery. However, underlying development needs in Papua New Guinea still remain to be fully addressed. The dominance of the natural resource sector has hindered the development of nonmineral sectors of the economy. Poor infrastructure, weak governance, and an unattractive business environment have constrained more rapid growth. Although recent growth rates have been strong relative to the past, the growth performance gap relative to comparator countries is widening. Poverty and unemployment remain

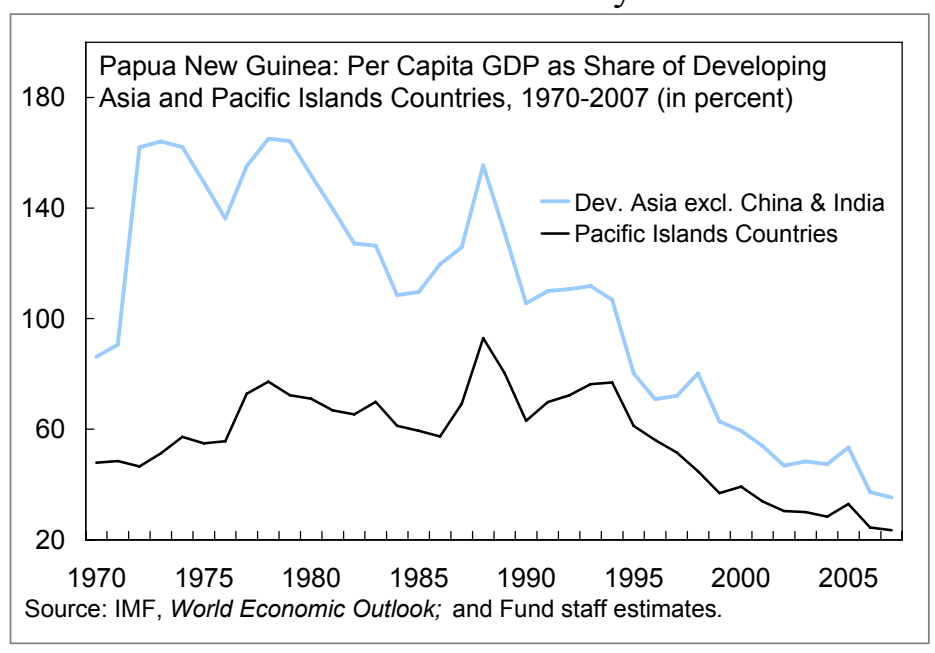
high as the economy is unable to absorb a rapidly growing labor force. ${ }^{1}$

3. Recent developments have introduced new uncertainty to the outlook as the midyear parliamentary elections draw closer. Frequent cabinet changes over the past year, including in key economic ministries, have complicated macroeconomic policy-making. The PNG-Queensland gas pipeline project, originally expected to start construction in late 2006, was put on hold following a recent reassessment by foreign partners.

\footnotetext{
${ }^{1}$ Unemployment data are unavailable, but anecdotal evidence suggests it is about 40 percent of the labor force in major urban centers, such as Port Moresby.
} 


\section{Box 1. Medium-Term Development Strategy}

The April 2005 Medium-Term Development Strategy (MTDS) sets out the government's development priorities for 2005-10, consistent with their Millennium Development Goals. The MTDS objectives are to: (i) establish good governance; (ii) promote export-driven growth in agriculture, forestry, fisheries, and tourism; and (iii) accelerate rural development and poverty reduction, through:

- $\quad$ public sector reform with improved accountability, reduced costs, more efficient service delivery, and fiscal sustainability;

- a more favorable climate for private sector activity through improved law and justice, expanded telecommunications, development of human resources, and upgraded transportation infrastructure; and

- $\quad$ redirecting public expenditure toward the priority areas of rural and transportation infrastructure, basic education, law and justice, and preventive health care programs, including for HIV/AIDs.

Almost two years after the strategy's inception, progress has stalled in many areas. An important advance has been in shifting a larger share of budgeted expenditure toward infrastructure and human capital. However, the MTDS's objectives remain valid and a point of reference for the public. 
Figure 1. Papua New Guinea: Progress Toward Selected Millennium Development Goals 1/

Although some progress has been made, there remains some distance before MDG goals will be met.
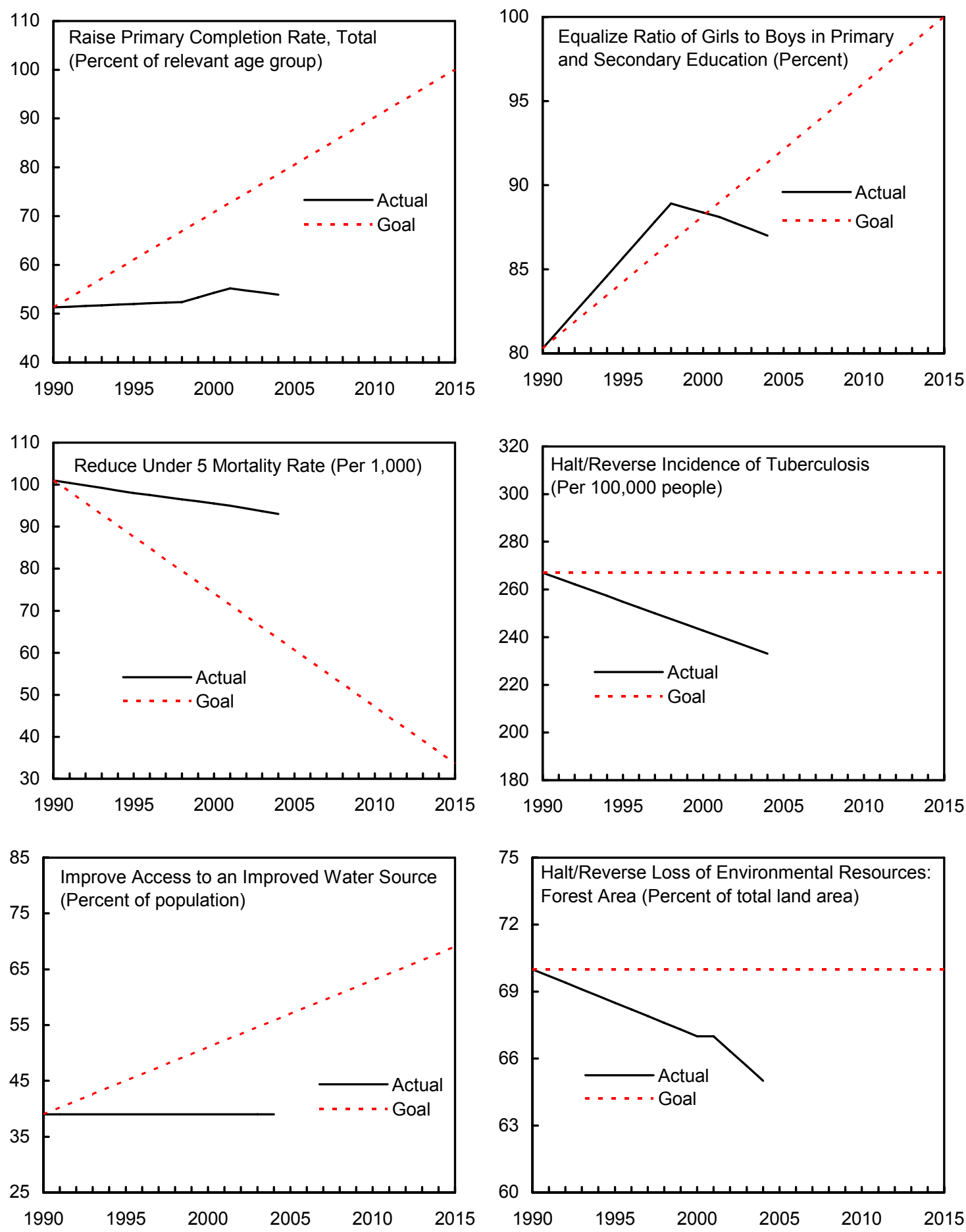

Source: World Bank, World Development Indicators database, September 2006.

1/ Progress is measured against a linear projection between the 1990 level and the MDG.

Data points may not be available for each intervening year. 


\begin{tabular}{|c|c|c|}
\hline \multicolumn{3}{|c|}{ Review of Past Fund Surveillance } \\
\hline \multirow{2}{*}{ Fund Policy Advice in 2002-03 } & \multicolumn{2}{|c|}{$\begin{array}{l}\text { Status } \\
\end{array}$} \\
\hline & 2004 Article IV Consultation & 2006 Article IV Consultation \\
\hline $\begin{array}{l}\text { Reduce fiscal deficits ( }-5 \text { percent of } \\
\text { GDP) and public debt ( } 72 \text { percent GDP). }\end{array}$ & $\begin{array}{l}\text { Fiscal deficit in balance and debt } \\
\text { reduced to } 60 \text { percent of GDP. }\end{array}$ & $\begin{array}{l}\text { Consecutive fiscal surpluses since } \\
2004 \text {; debt lowered further to } 39 \\
\text { percent of GDP in } 2006 \text {. }\end{array}$ \\
\hline $\begin{array}{l}\text { Reduce nonpriority spending, including } \\
\text { wage bill, to provide room for priority } \\
\text { expenditure such as infrastructure and } \\
\text { education. }\end{array}$ & $\begin{array}{l}\text { Little progress; } 2004 \text { budget } \\
\text { provided for } 3 \text { percent wage } \\
\text { increase and additional } \\
\text { performance bonuses. }\end{array}$ & $\begin{array}{l}\text { Current spending, including wage bill, } \\
\text { reduced as share of GDP. Budget } \\
\text { focus on infrastructure expenditure, but } \\
\text { execution capacity weak. "Right-sizing" } \\
\text { report completed, but implementation } \\
\text { delayed until after } 2007 \text { elections. }\end{array}$ \\
\hline $\begin{array}{l}\text { Monetary policy should aim at reducing } \\
\text { inflation and gradually relaxing interest } \\
\text { rates. }\end{array}$ & $\begin{array}{l}\text { Inflation and interest rates brought } \\
\text { down to low single digits. }\end{array}$ & Inflation and interest rates remain low. \\
\hline $\begin{array}{l}\text { Strengthen operations of public } \\
\text { enterprises with view to possibly } \\
\text { privatize in medium term. }\end{array}$ & $\begin{array}{l}\text { No significant progress. Most } \\
\text { enterprises continued to run } \\
\text { losses. }\end{array}$ & $\begin{array}{l}\text { Financial positions have improved but } \\
\text { still slow progress in improving service } \\
\text { delivery. No privatization planned. }\end{array}$ \\
\hline $\begin{array}{l}\text { Create business-friendly environment to } \\
\text { encourage growth and job creation in } \\
\text { nonmineral sector. }\end{array}$ & $\begin{array}{l}\text { Limited progress in easing } \\
\text { constraints, e.g., weak law-and- } \\
\text { order and infrastructure. }\end{array}$ & $\begin{array}{l}\text { Little further progress; however, } \\
\text { budgeted spending increase for } \\
\text { rehabilitating infrastructure. }\end{array}$ \\
\hline $\begin{array}{l}\text { Progress on multi-year tariff reform } \\
\text { program. }\end{array}$ & On track. & $\begin{array}{l}\text { Completed in early } 2006 \text {; some } \\
\text { backtracking in } 2007 \text { budget. }\end{array}$ \\
\hline
\end{tabular}

\section{BACKGROUND}

\section{A. The Economic Setting}

\section{Recent developments and the near-term outlook remain favorable (Tables 2-5}

and Figures 2-7). High commodity prices and expanding mineral production should contribute to continued growth and fiscal and external surpluses (Box 2).

- The recovery is expected to gain steam in 2007, with growth rising to over 4 percent, as new mines begin production and increased government spending stimulates activity in the nonmineral sector.

- Inflation, estimated at 3.5 percent on average in 2006, is expected to rise slightly in 2007 as fiscal spending increases pressure on prices, but remain consistent with the Bank of Papua New Guinea's (BPNG) 4 percent medium-term inflation objective.

- $\quad$ The current account surplus should narrow in 2007 as the value of mineral exports begins to decline with lower prices expected for key exports. Official external reserves should increase to about $\$ 1.6$ billion ( 4 months of goods and services imports). 
Figure 2. Papua New Guinea: Real Sector Developments

Volatile mineral sector developments and poor economic management, together with rapid population growth, resulted in GDP per capita little improved since independence in 1975 until early years of 2000.

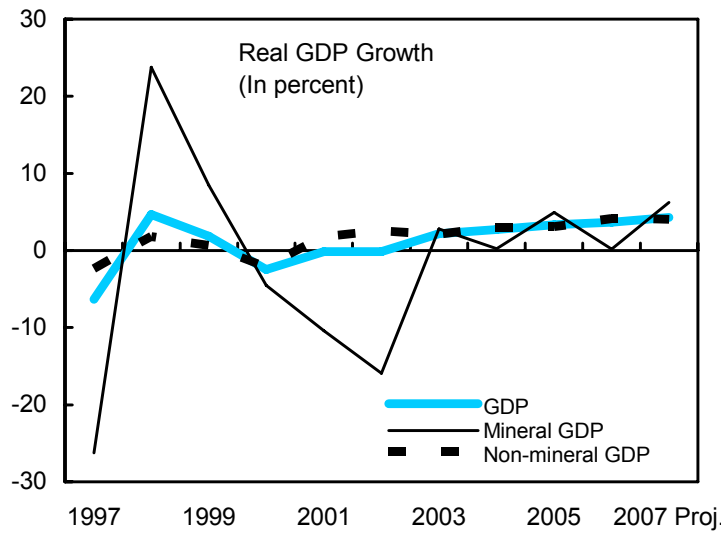

But since 2003, sound policies have contributed to economic recovery and lower inflation.

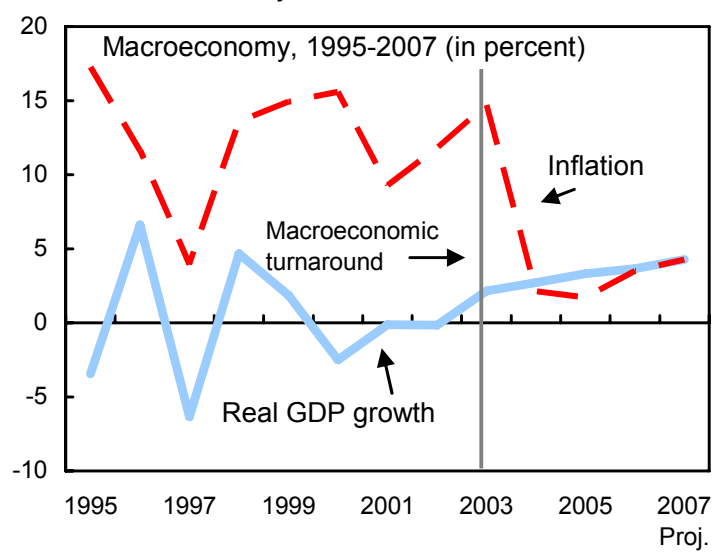

Including relative to comparators.

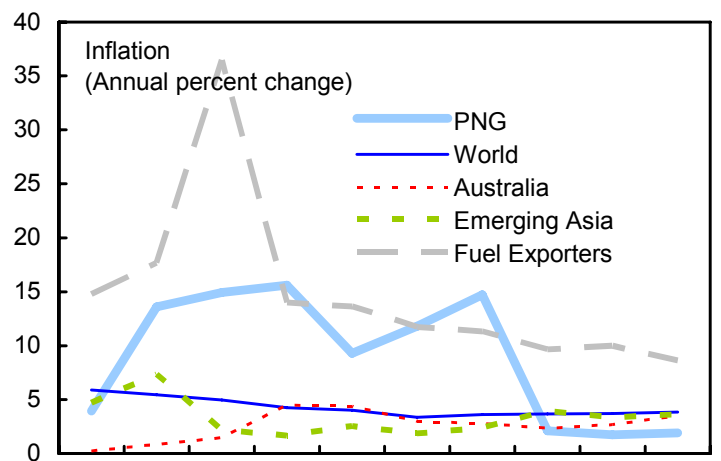

1997199819992000200120022003200420052006

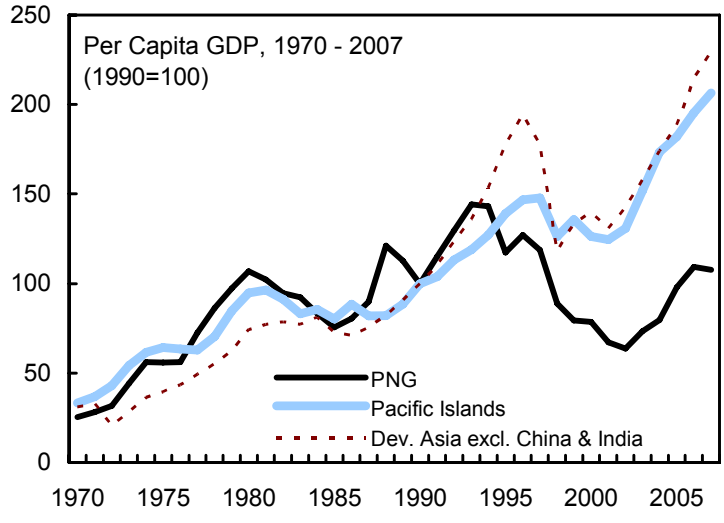

Fiscal and monetary discipline, and kina appreciation, led to sharply reduced $\mathrm{CPI}$ inflation...

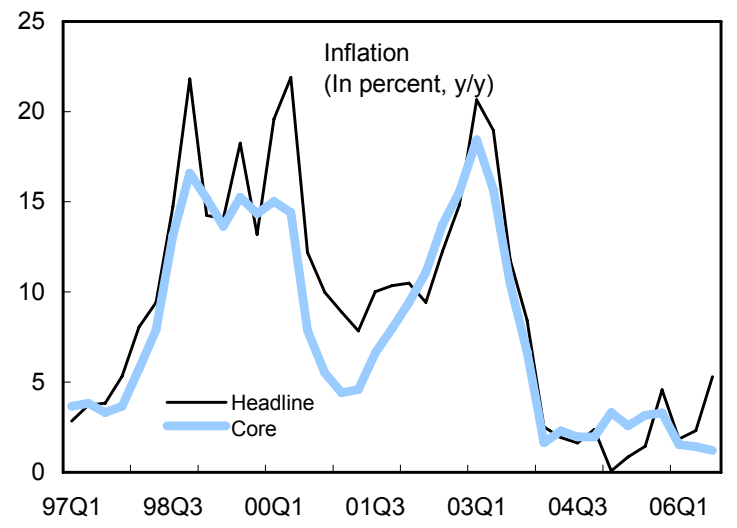

However, human development indicators remain poor.

\begin{tabular}{|lccc|}
\hline \multicolumn{4}{|c|}{ PNG and Comparator Countries } \\
\hline & \multicolumn{4}{c}{$\begin{array}{c}\text { GDP per } \\
\text { HDI Rank } \\
\text { Capita in US\$ } \$ \\
(2005)\end{array}$} & $\begin{array}{c}\text { Real GDP } \\
\text { per Capita } \\
\text { Avg Growth } \\
2002-05\end{array}$ \\
\hline Pacific Islands & 94 & 2157 & 0.55 \\
Developing Asia & 107 & 1200 & 7.01 \\
Cambodia & 129 & 430 & 6.98 \\
Papua New Guinea & 139 & 855 & -0.39 \\
Sub Sahara Africa & 148 & 850 & 2.21 \\
\hline 1/ Human Development Indicators, higher rank = lower level of \\
development.
\end{tabular}

Sources: Papua New Guinea authorities; IMF, World Economic Outlook; UN, Human Development Report, 2006; and Fund staff estimates. 
Figure 3. Papua New Guinea: External Sector Developments

High world prices for key export commodities are driving surpluses on the external accounts.
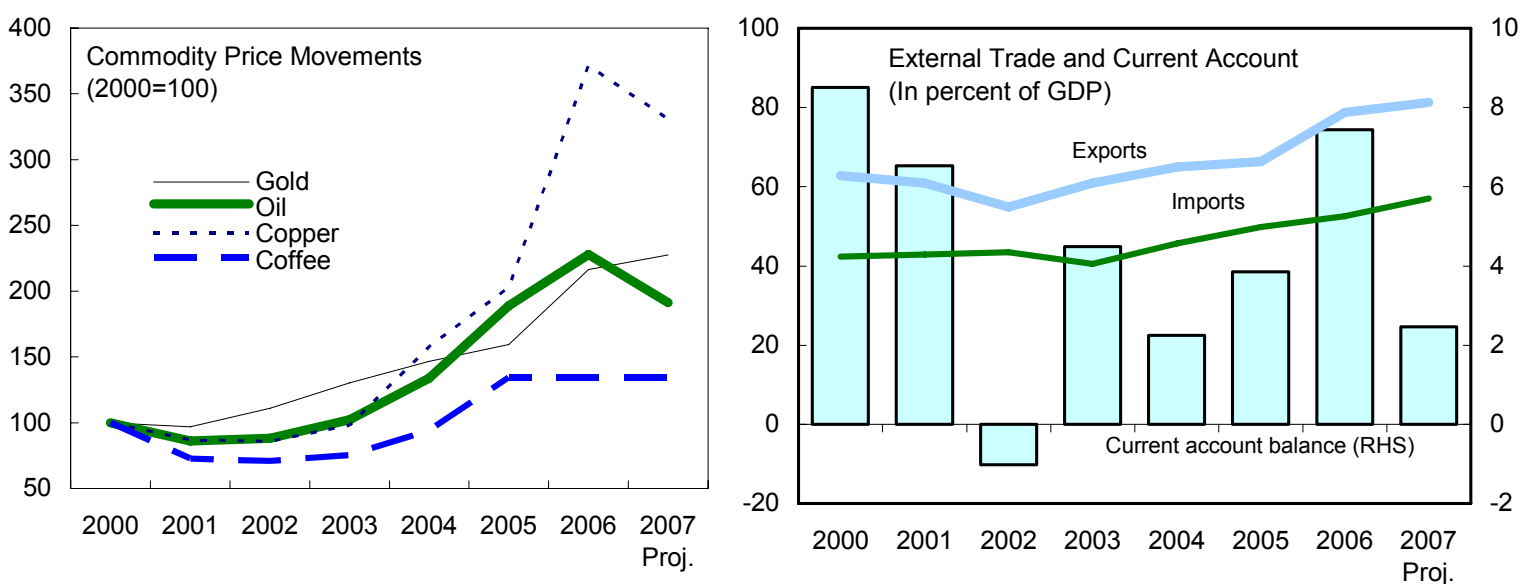

High mineral prices are pushing up both mineral sector exports and imports, as construction on new mines begins.

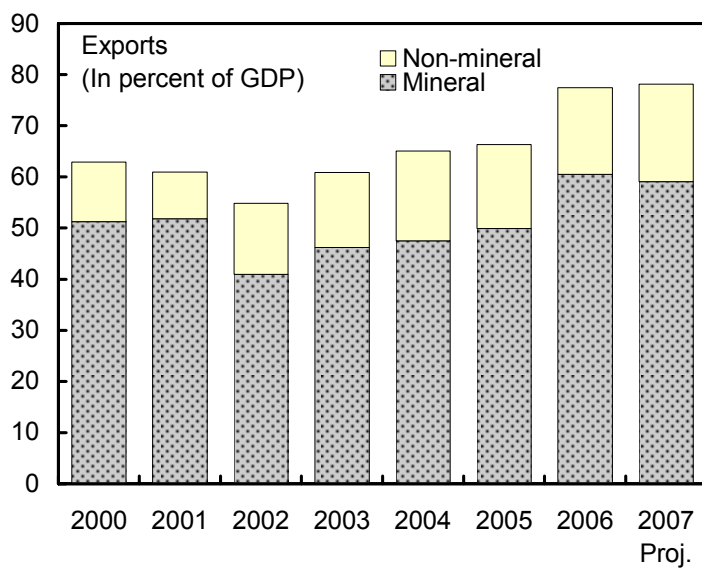

External reserves are growing, though they are still not large relative to comparators (Box 4),

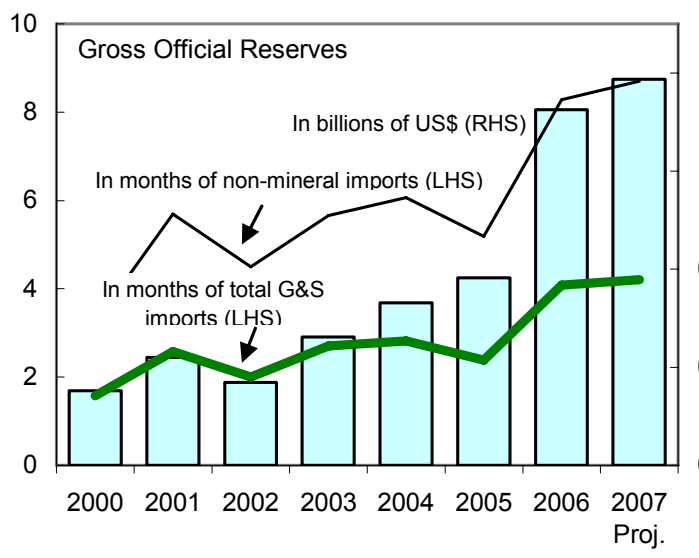

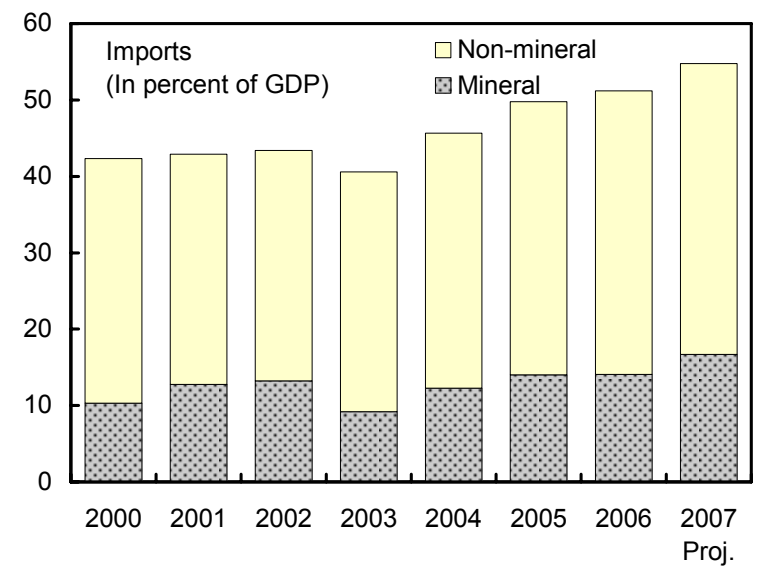

The kina continues to appreciate steeply on a real effective basis, though less so against the US\$.

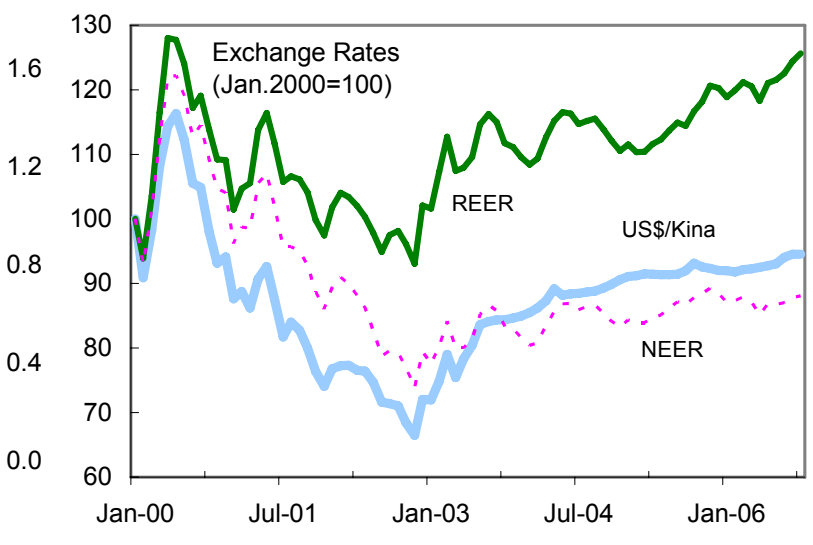

Sources: Papua New Guinea authorities; IMF World Economic Outlook and Information Notice System; and Fund staff estimates. 
Figure 4. Papua New Guinea: Fiscal Sector Developments

An overall fiscal surplus is expected for the 3rd year in 2007. Nonmineral imbalances are widening, reflecting higher development spending financed by record mineral revenue inflows.

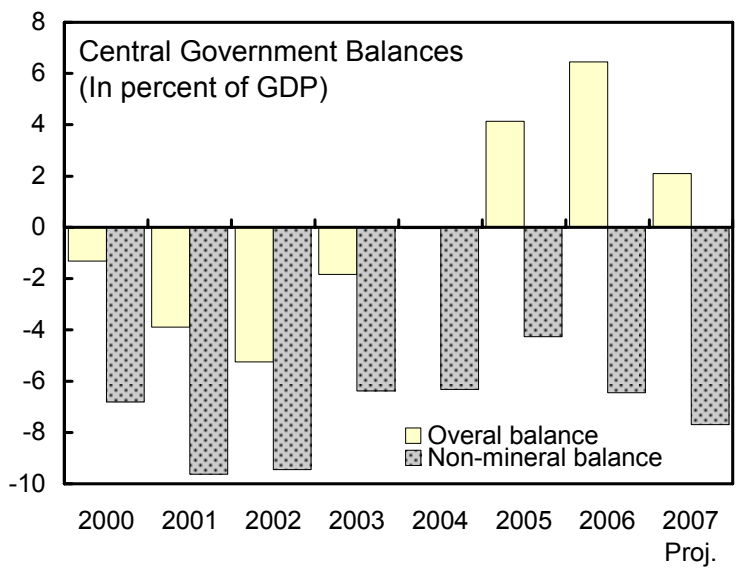

The fiscal consolidation begun in 2002 should continue.

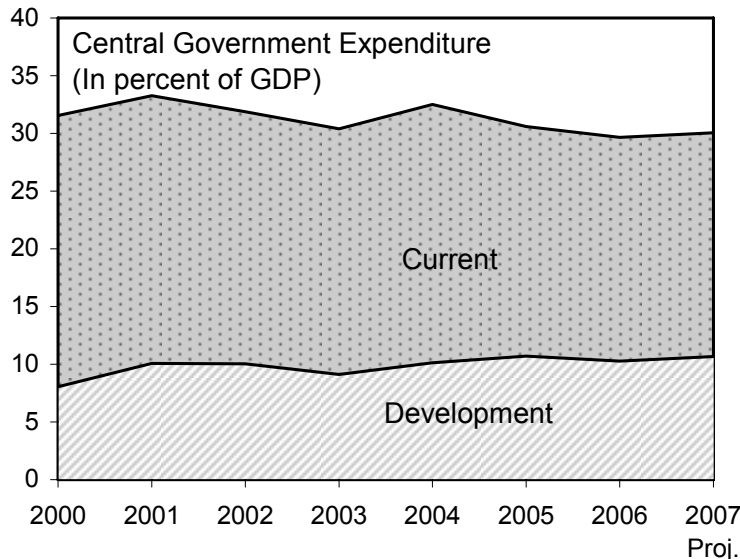

Positive debt dynamics and some repayment of debt in 2006 has lowered the debt burden,

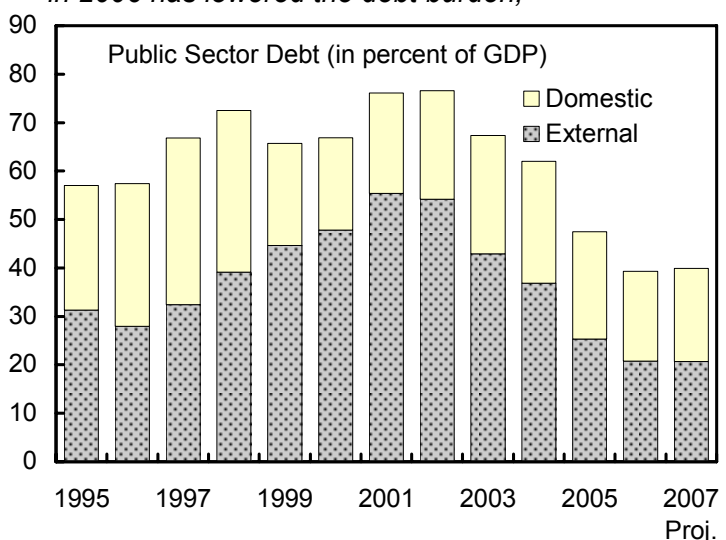

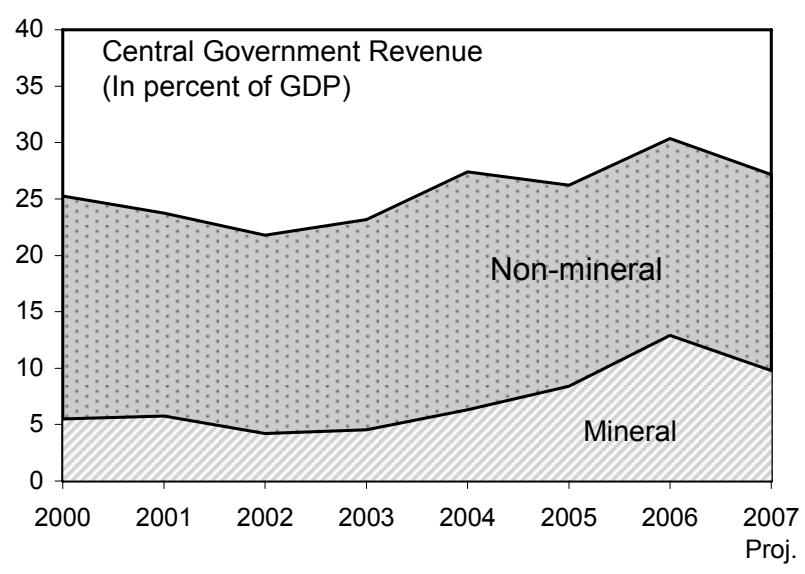

Current spending is expected to continue to decline, if the budget is respected.

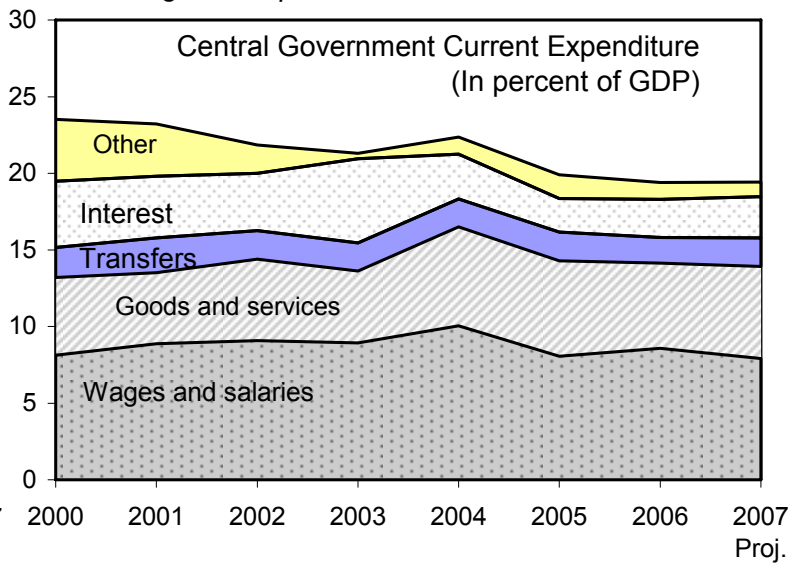

signaling an improvement relative to regional comparators.

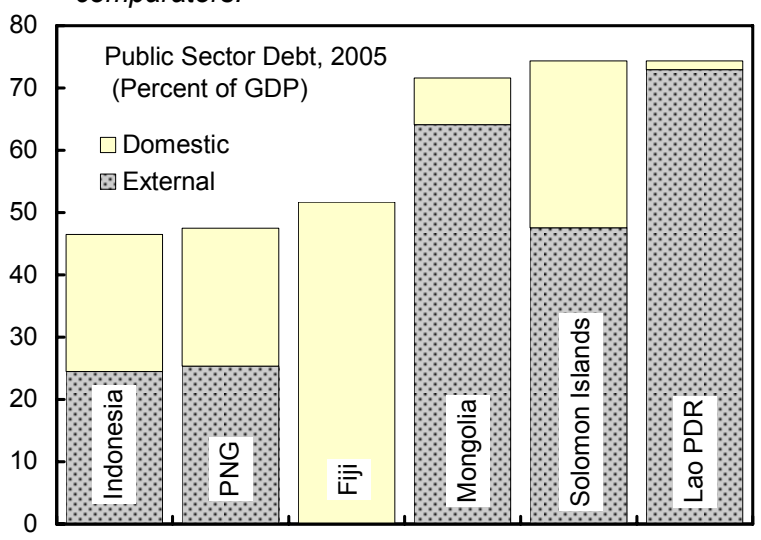

Sources: Papua New Guinea authorities; IMF World Economic Outlook; and Fund staff estimates. 
Figure 5-A. Papua New Guinea: Monetary Developments

Although money supply and credit growth are strong, in the current low inflation environment, monetary policy remains relaxed.
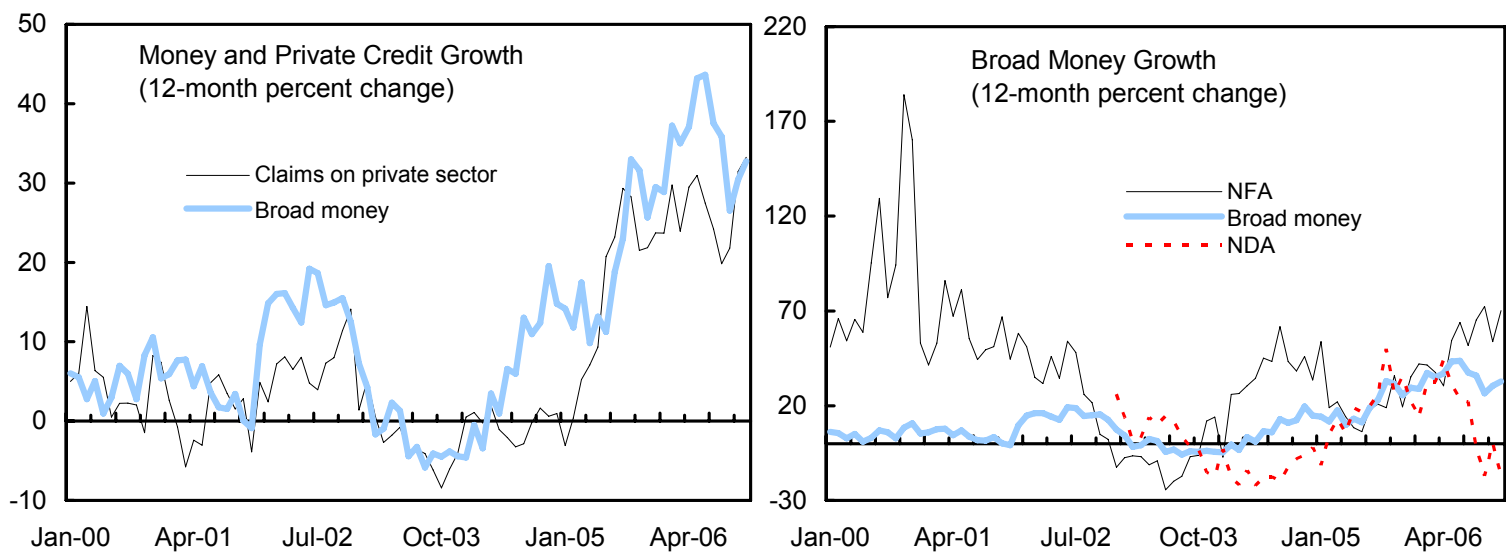

Interest rates were reduced sharply, relative to regional policy rates...
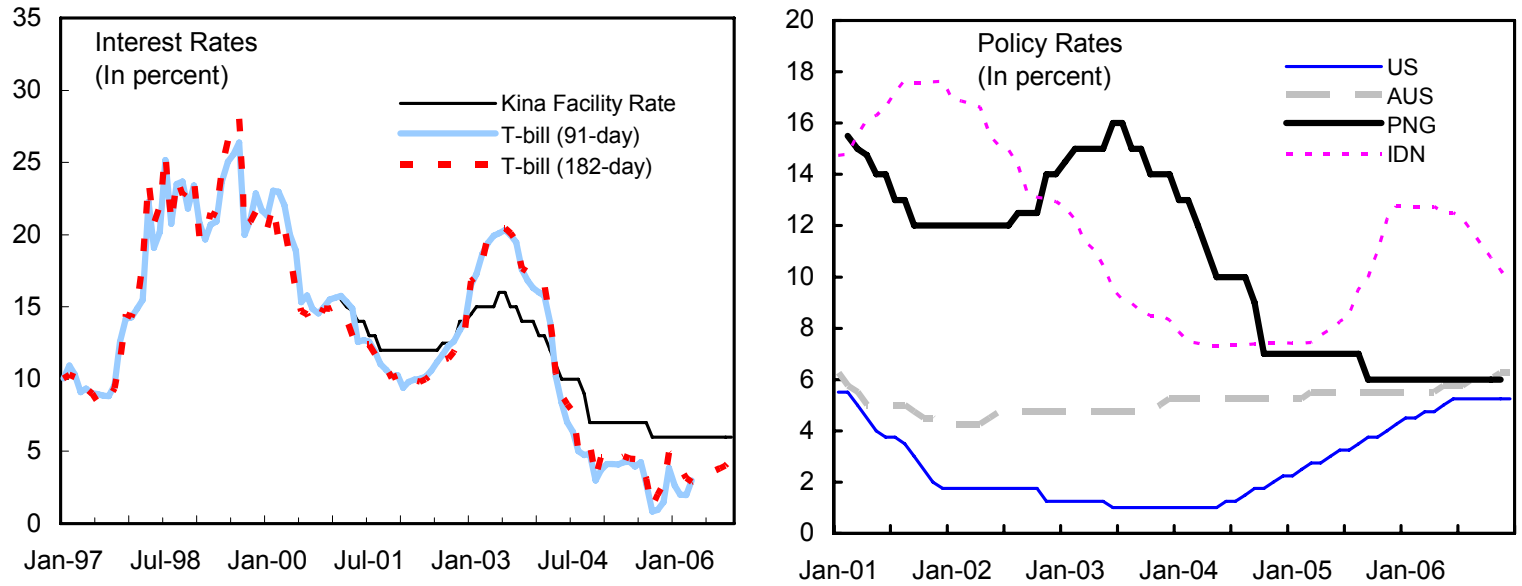

....and to regional market rates.

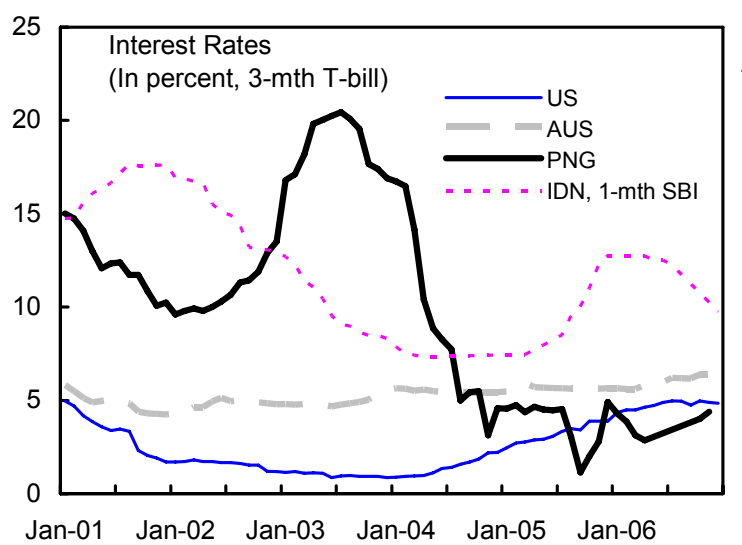

The BPNG intervenes to absorb liquidity.

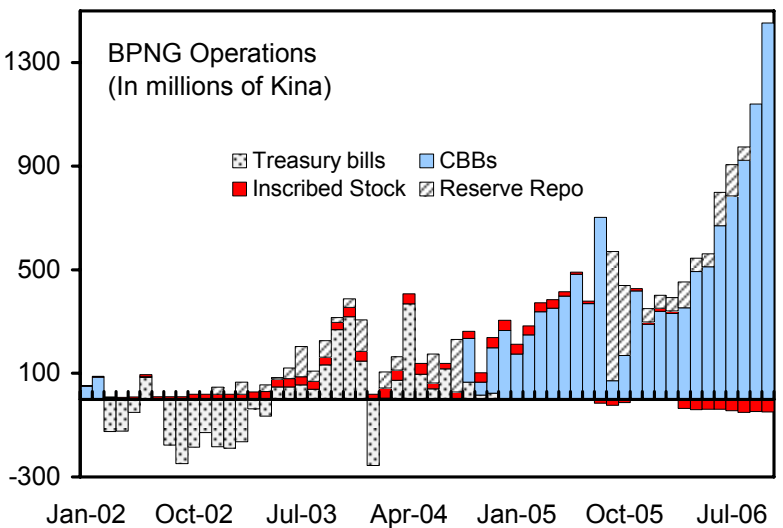

Sources: IMF, Monetary and Financial Statistics; Bloomberg; Papua New Guinea authorities; and Fund staff calculations. 
Figure 5-B. Papua New Guinea: Monetary Developments (continued)

...To keep reserve money within target range.

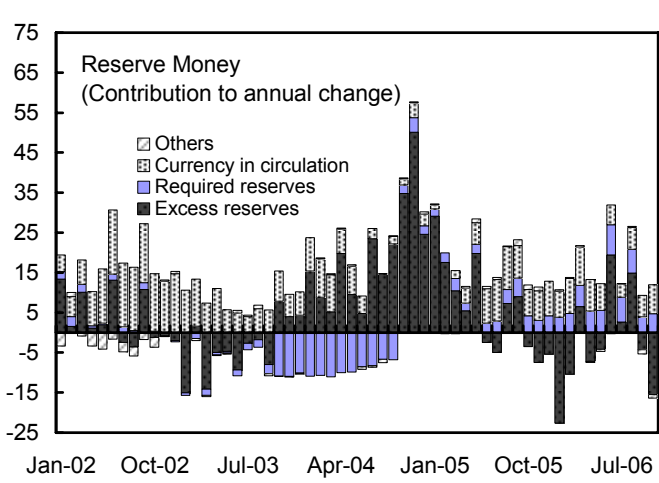

Domestic credit growth appears relatively broad based.

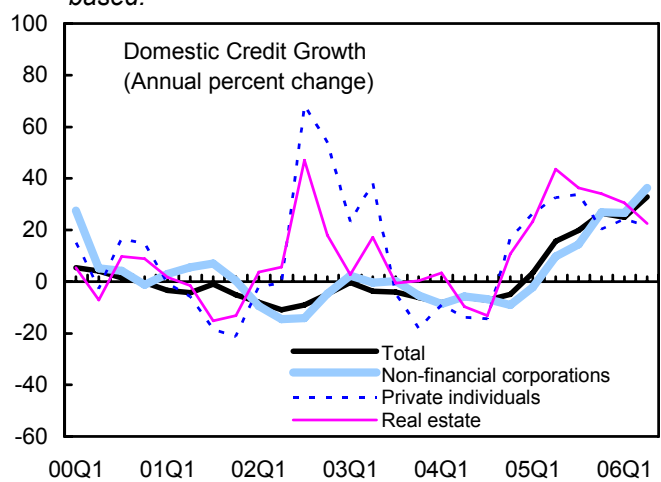

Although credit growth has been rapid, relative to GDP it has just regained levels existing prior to the economic downturn and remains low relative to comparators.
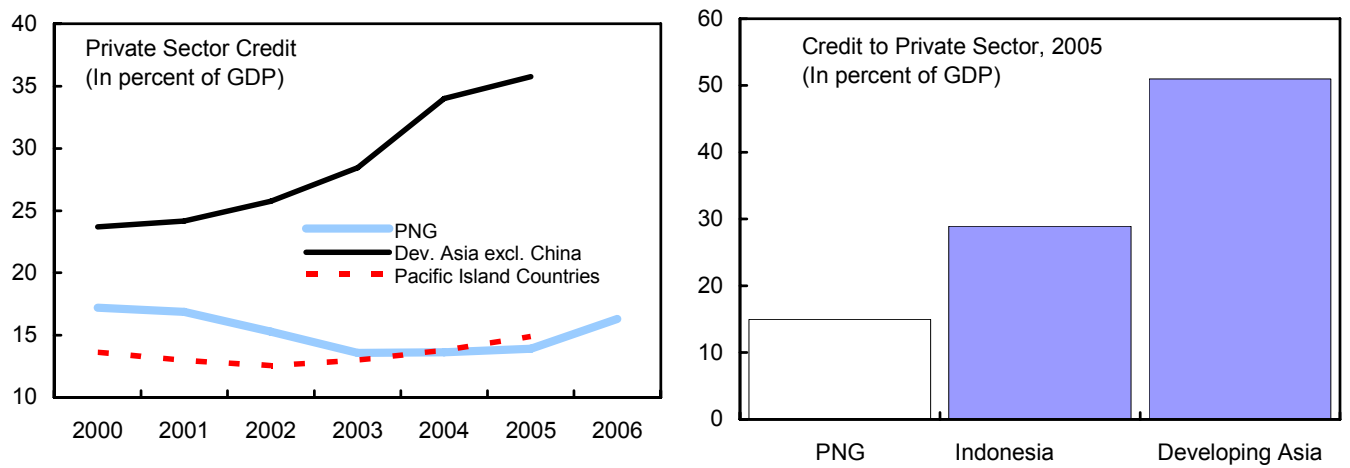

Financial sector indicators, including non-performing loans and return on assets, indicate the sector is healthy.
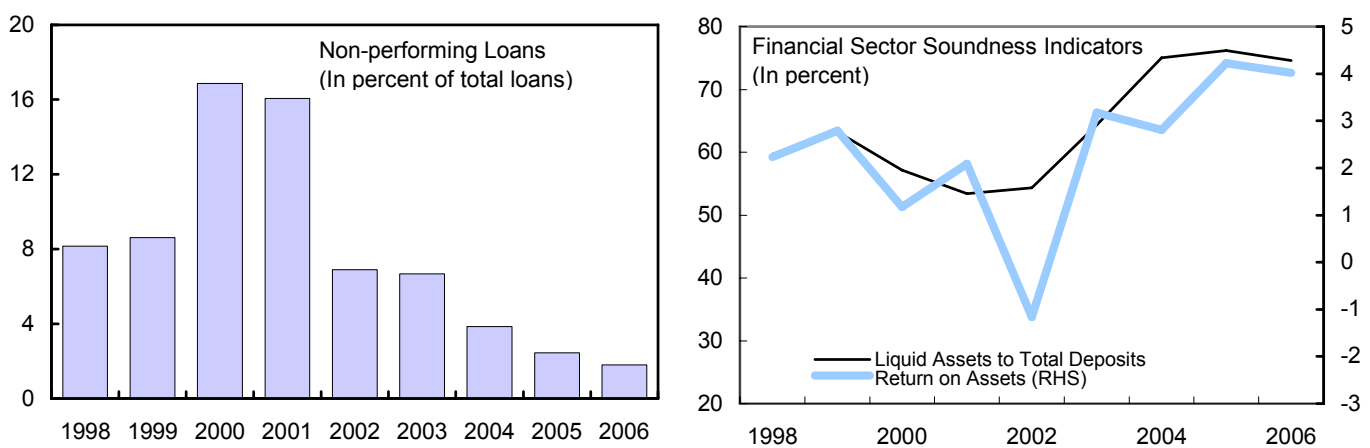

Sources: IMF, International Financial Statistics; Papua New Guinea authorities; and Fund staff calculations. 
Figure 6. Papua New Guinea: Regional and Global Comparators, 2004-06

Macroeconomic performance has improved in recent years, although real economic growth is still below most comparators while population growth remains high.

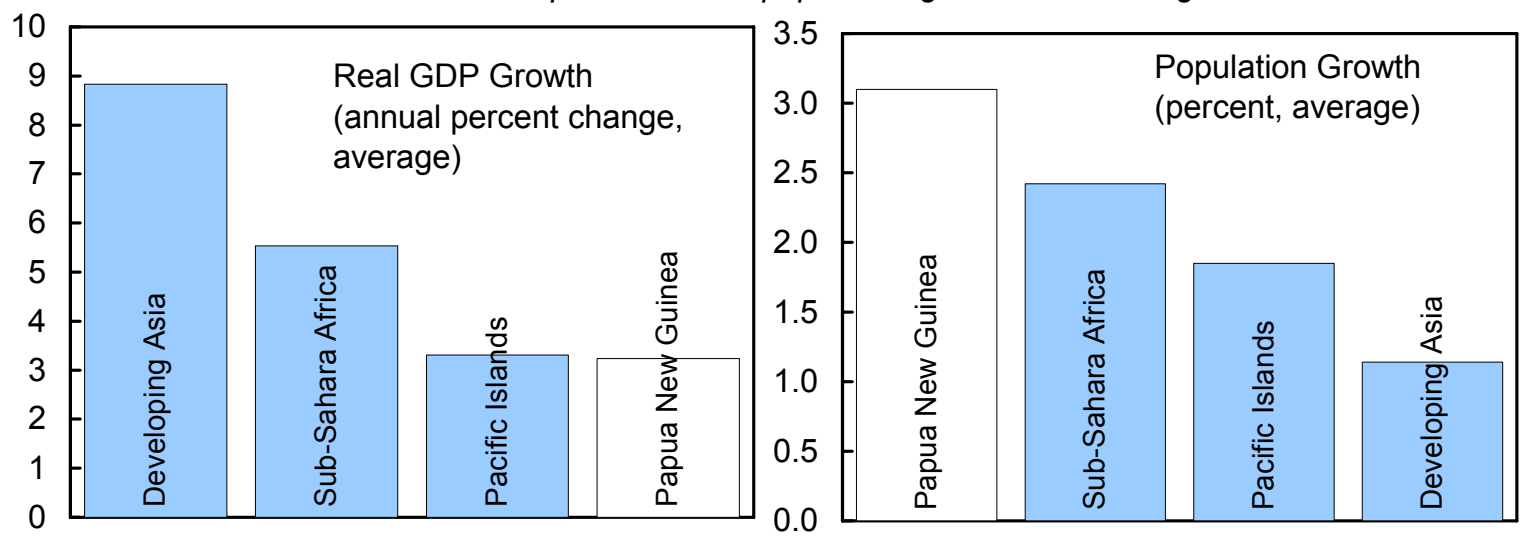

However, good macroeconomic policies led to a reduction in inflation to levels that compare favorably... while fiscal accounts moved into surplus...

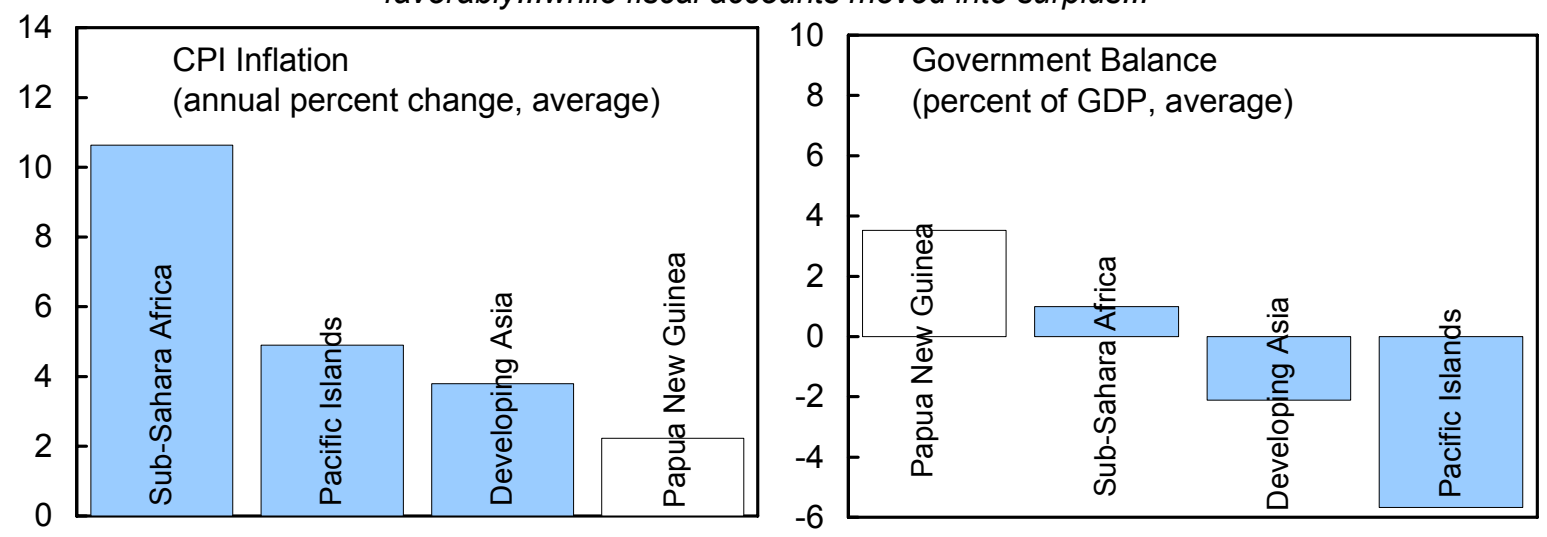

Resulting in improved external debt levels and official external reserves.
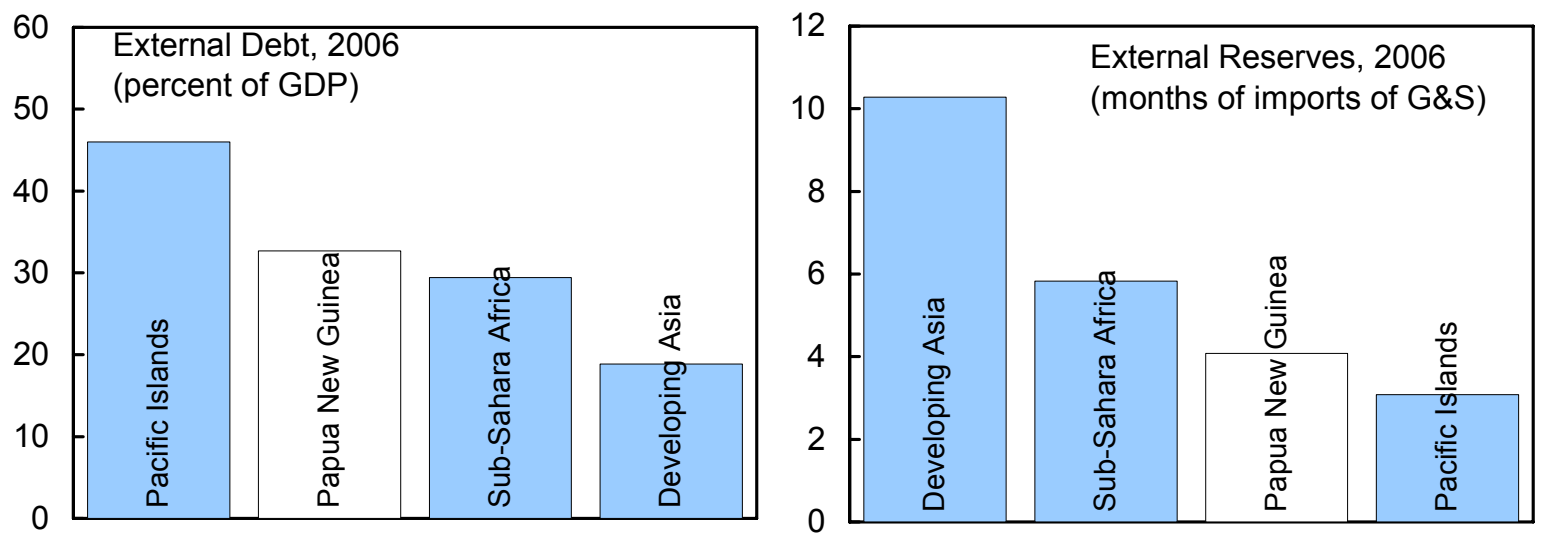

Sources: IMF, World Economic Outlook; Papua New Guinea authorities; and Fund staff calculations. 
Figure 7. Papua New Guinea: Regional and Global Comparators

Oil reserves are small and rapidly being depleted.

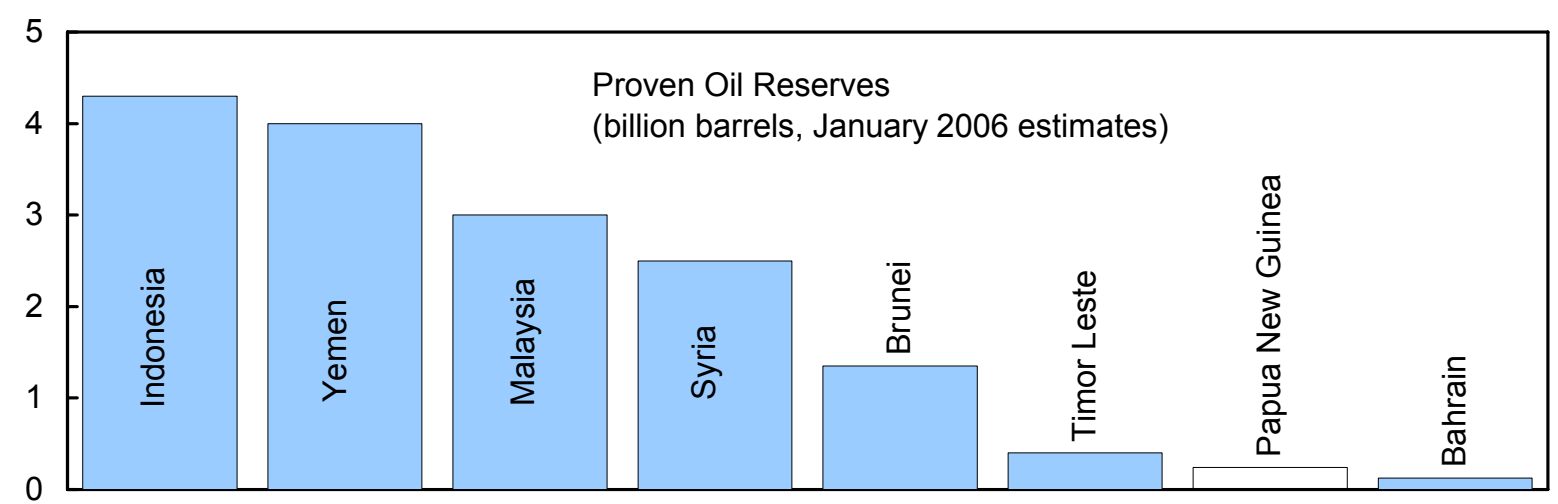

But gas reserves are more promising and new fields may come on line in the future.

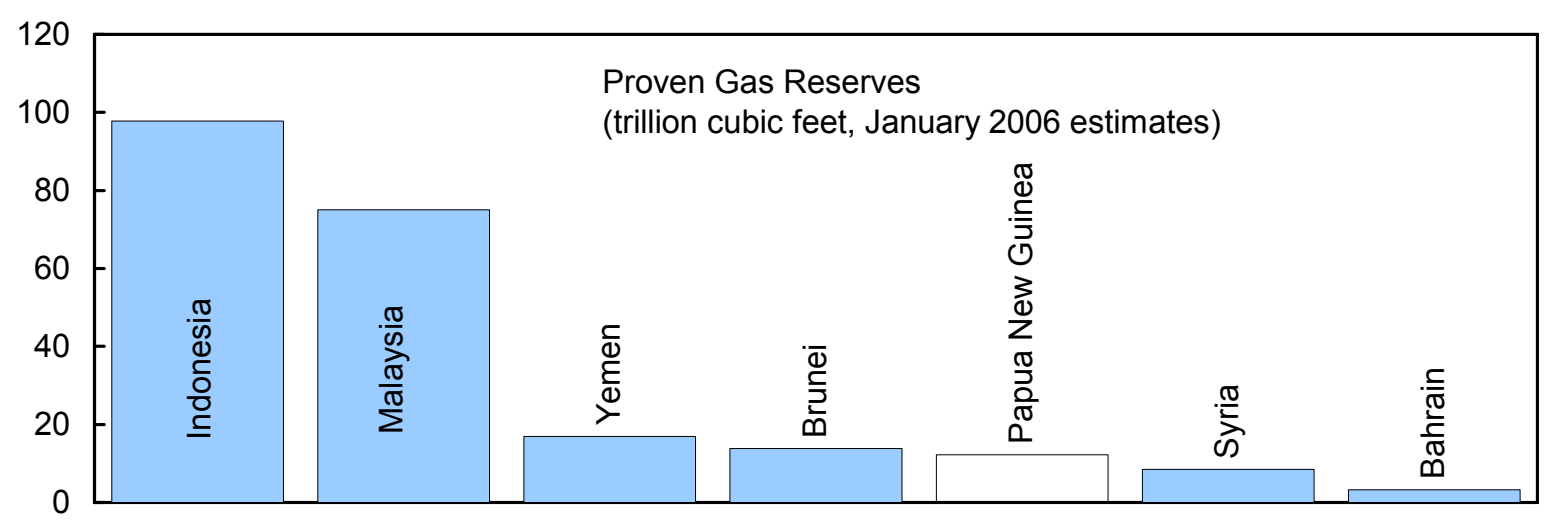

However, although important, government mineral revenue remains low relative to comparators.

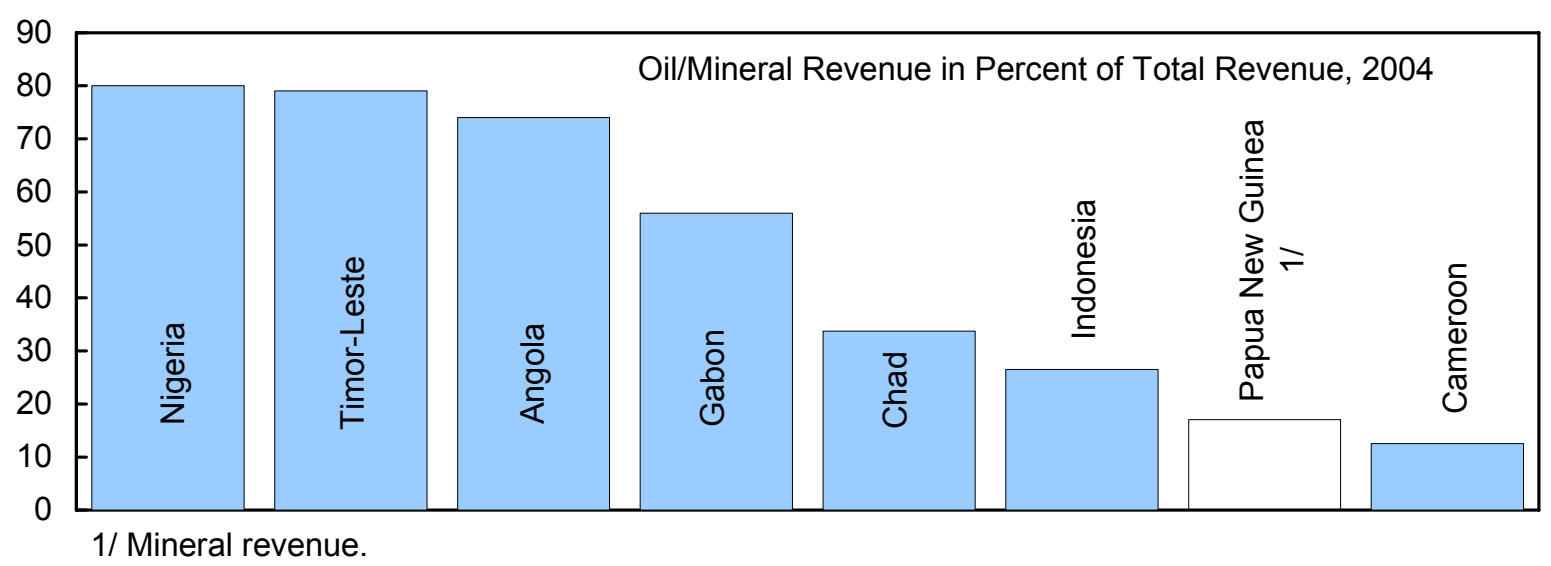

Sources: Country authorities; and Oil \& Gas Journal. 


\section{Box 2. Role of the Mining Sector in Papua New Guinea}

The mining sector (including petroleum and natural gas) dominates Papua New Guinea's economy. Once considered a sector in decline, the recent surge in mineral prices has spurred investment in existing mines to expand production and in new exploration as reflected in a sharp rise in mineral exploration applications. The outlook hinges on whether planned projects come on stream before expected declines in mineral prices dampen activity once more.

Gold and silver (27 percent of exports): The largest mine (Lihir) is expanding output with new investment, a second sizeable mine (Kainantu) recently began operations, and several new small mines should start production over the next 2-3 years. The life of another large mine (Porgera) will likely be longer than previously expected.

Copper (27 percent of exports), nickel, and other minerals: Copper production from the Ok Tedi mine is expected to decline steadily from its recent highs, albeit over a longer timeframe than previously envisaged. The large Ramu nickel mine is expected to begin construction in 2007, with production commencing in 2010 .

Oil (23 percent of exports): production volumes should remain flat during $2007-10$, followed by a gradual decline thereafter.

Natural gas: Following the late-2006 discovery of natural gas in Papua New Guinea's Gulf region, the largest producer, InterOil, has announced new exploration bids. However, the $\$ 5.3$ billion PNGQueensland Gas Pipeline Project tapping natural gas reserves located in Papua New Guinea's Highlands region is now unlikely to materialize after the external partners' recent negative reassessment of the project's viability due to increasing costs. The government is considering alternative options for use of the Highland's gas reserves and another project may be developed if prices remain high.
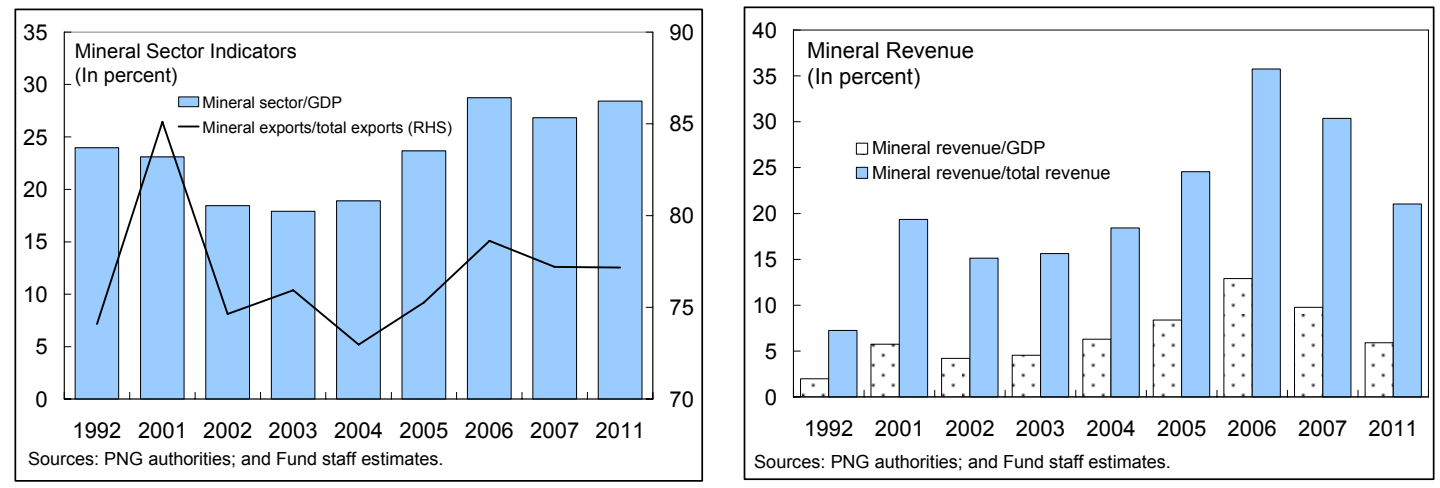
- After a steep rise in the kina's value in 2003-05, it appreciated by 3 percent against the U.S. dollar and 6 percent on a real effective basis in 2006.

- An overall fiscal surplus is expected for the third successive year in 2007, although the underlying nonmineral deficit would further widen due to higher spending and lower nonmineral tax revenue (largely reflecting the phased reduction in the personal income tax). The 2006-07 budgets provide for large spending increases mainly for development expenditure (over three quarters of the total increase), much of it oneoff, and smaller allotments for public enterprise investment, natural disaster victims, and domestic arrears clearance. Given weak implementation capacity and the late timing of the 2006 supplementary budgets, the spending outcome is expected to be significantly less than appropriated. The remaining amounts would be deposited in trust fund accounts for future spending.

\begin{tabular}{|c|c|c|c|c|c|c|}
\hline \multicolumn{7}{|c|}{ Papua New Guinea: Summary of Central Government Operations, 2005-07 } \\
\hline & \multirow[t]{2}{*}{2005} & \multicolumn{3}{|c|}{2006} & \multicolumn{2}{|c|}{2007} \\
\hline & & Budget & $\begin{array}{c}\text { Revised } \\
\text { Budget 1/ } \\
\end{array}$ & Est. & Budget & Proj. \\
\hline & \multicolumn{6}{|c|}{ (In percent of GDP) } \\
\hline Revenue and grants & 34.2 & 27.0 & 35.3 & 36.1 & 30.3 & 32.1 \\
\hline Nonmineral revenue & 17.4 & 15.6 & 16.9 & 17.4 & 16.8 & 17.4 \\
\hline Mineral revenue & 8.4 & 5.7 & 12.6 & 12.9 & 8.4 & 9.8 \\
\hline Grants & 8.0 & 5.8 & 5.8 & 5.8 & 5.0 & 5.0 \\
\hline Total expenditure and net lending & 30.6 & 27.6 & 34.7 & 29.7 & 30.5 & 30.1 \\
\hline Recurrent expenditure & 19.9 & 18.2 & 19.4 & 19.4 & 19.4 & 19.4 \\
\hline Salaries and wages & 8.0 & 7.8 & 8.6 & 8.6 & 7.9 & 7.9 \\
\hline Goods and services & 6.2 & 5.1 & 5.6 & 5.6 & 6.0 & 6.0 \\
\hline Other & 5.6 & 6.2 & 6.0 & 6.1 & 6.5 & 6.5 \\
\hline Development expenditure & 10.7 & 9.4 & 14.7 & 10.3 & 11.1 & 10.7 \\
\hline Net lending $2 /$ & 0.0 & 0.0 & 0.6 & 0.0 & 0.0 & 0.0 \\
\hline Overall balance $3 /$ & 3.6 & -0.5 & 0.6 & 6.4 & -0.2 & 2.1 \\
\hline Nonmineral overall balance $3 /$ & -4.8 & -6.2 & -12.0 & -6.5 & -8.6 & -7.7 \\
\hline \multicolumn{7}{|c|}{$\begin{array}{l}\text { 1/ Includes supplementary budgets passed in August and November } 2006 \text {. } \\
2 \text { / In } 2006 \text {, the budget treats savings for a future acquisition of an equity participation in the } \\
\text { PNG gas project as an expenditure. Under IMF's GFS standards, these are treated as } \\
\text { expenditure for loan repayment. }\end{array}$} \\
\hline
\end{tabular}

- Repayment of 0.5 percent of GDP of external debt in 2006 to the Asian Development Bank (AsDB) combined with positive debt dynamics (real GDP growth, kina appreciation, and low interest rates) should contribute to a public sector debt-to-GDP ratio of 40 percent in 2007. 


\section{B. Medium-Term Outlook and Risks}

5. The macroeconomic outlook should remain positive, if fiscal and monetary policies are maintained on their current path (Table 6 and Figure 8). Real GDP growth of about 4 percent is expected over the medium term, together with continued low inflation rates. Falling export prices should underlie narrowing external current account surpluses. The nonmineral fiscal deficit is expected to improve gradually after 2007, if one-off spending in the 2006-07 budgets is not carried over and the "right sizing" program to streamline the government is implemented.

6. The balance of risks is to the downside. Higher-than-expected election-related spending could lead to increasing price pressures; the resulting rise in interest rates as monetary policy is tightened could choke off economic growth. Still weak fiscal accountability, especially for many trust funds, also poses risks of higher or inefficient spending. A steeper-than-anticipated decline in world export commodity prices or postponement of large mineral projects would heighten the need for fiscal adjustment to allow room for essential development spending. ${ }^{2}$ Inaction or unwinding of previous progress on structural reform would dampen investor confidence. The further spread of HIV/AIDsalready one of the highest infection rates in the Asia-Pacific region-would have consequences for growth and human development. On the upside, rapid development of gas reserves could improve the longer-term outlook for growth.

\section{A doubling of the baseline growth rates would be needed to significantly reduce} poverty and unemployment. Stronger annual growth of 7-8 percent is within reach, but would require more effective use of Papua New Guinea's mineral wealth, including a sustainable medium-term fiscal policy that efficiently delivers needed development expenditure, and decisive efforts on structural reform to encourage greater activity in the nonmineral sector. The resulting strengthened fiscal position would improve the debt sustainability outlook.

\section{Papua New Guinea is at a moderate risk of debt distress, emphasizing the} importance of continued prudent fiscal policy (Appendix I). The staff's debt sustainability analysis (DSA) using the low-income country framework suggests that the public sector debt outlook is particularly sensitive to changes in real GDP growth and to the exchange rate. The authorities are keenly aware of these risks. The objective of their debt strategy targeting a reduction in the debt-to-GDP ratio over the medium term is to reduce these vulnerabilities.

\footnotetext{
${ }^{2}$ A 10 percent reduction in key export prices reduces government revenue by 0.5 percent of GDP annually.
} 
Figure 8. Papua New Guinea: Outlook Indicators
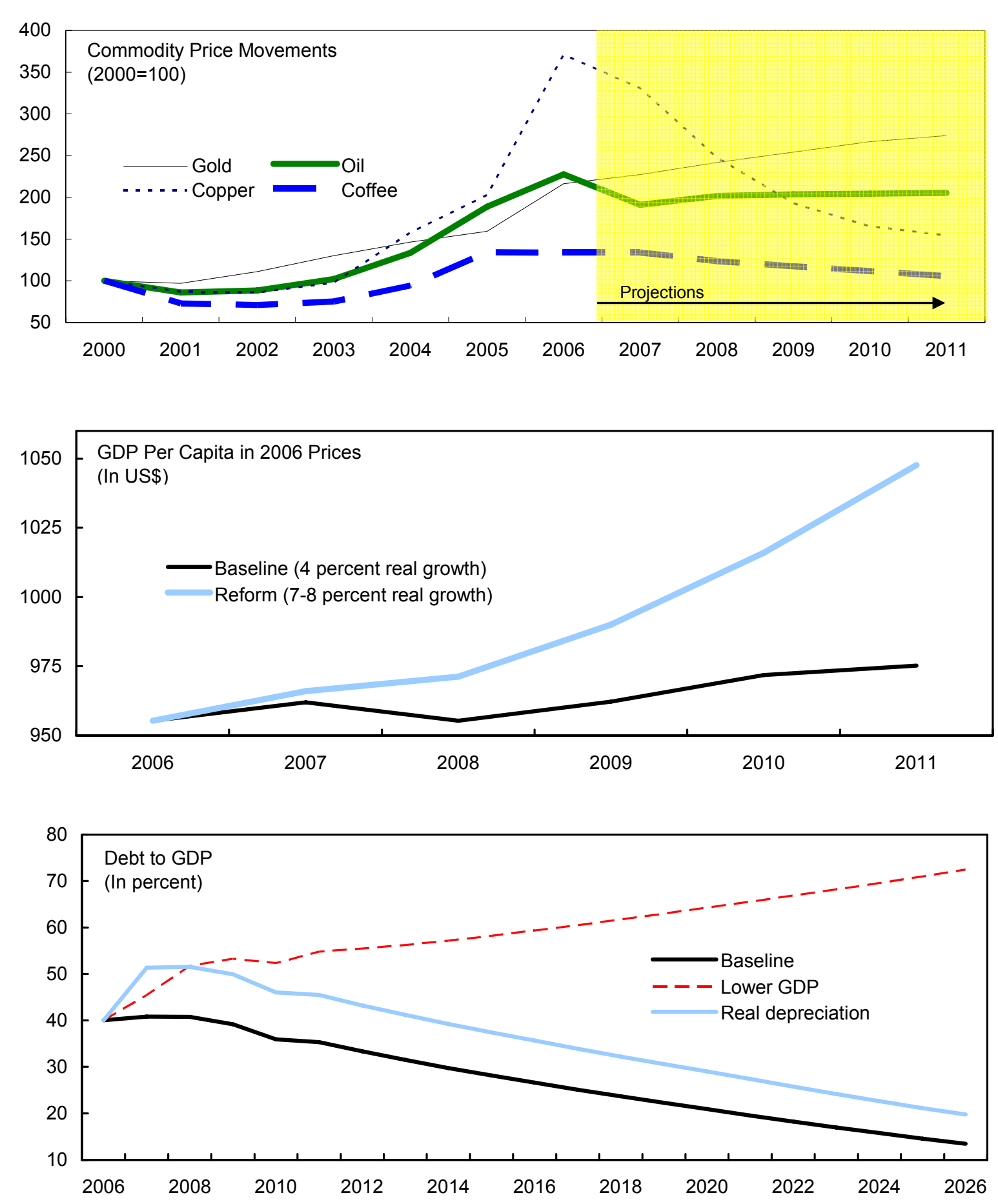

Sources: IMF, World Economic Outlook; Papua New Guinea authorities; and Fund staff calculations. 


\section{Policy Discussions}

9. The discussions focused on the short-term policy mix that would preserve macroeconomic stability and provide a bridge to a higher growth path in the future. The authorities and the staff broadly agreed on the main challenges facing Papua New Guinea and on the policy priorities needed to address them. In particular, the authorities were committed to avoiding the election-related fiscal policy excesses that in the past resulted in significant setbacks to the economy. In addition, while the current monetary and exchange rate policy was appropriate, a tightened stance would be needed should fiscal-related demand pressure emerge. Looking forward, in line with the objectives of the MTDS and the MDGs, the authorities and staff agreed on the need for renewed attention to the structural reform agenda to encourage private sector activity and raise growth in the nonmineral sector.

\section{A. Maintaining Macroeconomic Stability}

\section{Monetary and Exchange Rate Policy}

10. The staff views the current monetary policy stance as appropriate. The monetary and credit aggregates continue to rise at relatively rapid rates and liquidity in the banking system remains high. However, along with the continued appreciation of the kina, the BPNG has absorbed sufficient liquidity to keep inflation within the low single digits.

\section{Looking ahead, both the staff and the authorities see risks for inflation in 2007} and the possible need for tightening the monetary stance. The most serious concern arises from the risk of unproductive election-related government spending. In addition, pressure could emerge from expected upward revisions in controlled prices (although these would likely have a temporary impact), and sustained large mineral revenue inflows. In that light, the authorities and the staff agreed that monetary policy should be tightened if signs of inflation pressure emerged.

12. The authorities reaffirmed their commitment to a floating exchange rate regime. The authorities generally limit intervention to smoothing out fluctuations within a relatively thin market buffeted by volatile foreign exchange flows related to the mineral sector. Recently, they have used the opportunity of the current favorable terms of trade to build reserves, while protecting the competitiveness of the nonmineral sector by resisting rapid appreciation of the kina against the U.S. dollar. The staff supported this pragmatic approach, given:

- $\quad$ Mineral prices are not expected to remain at current highs, suggesting that the real exchange rate need not adjust upward permanently. The large current account surplus in 2006 is expected to dissipate over the medium term. 
- $\quad$ Foreign reserves have increased, but at 4 months of goods and services imports, they are not large relative to comparator countries (and are small relative to other natural resource exporters) (Box 3).

- $\quad$ Competitiveness indicators are mixed, but point to either little change or some decline in nonmineral sector competitiveness in recent years (Box 4), presenting an additional challenge for the nonmineral economy where sustained economic and employment growth must come from over the longer term.

However, as the authorities have neither the resources nor the record of fiscal discipline needed to defend a fixed rate, should upward pressure be unexpectedly sustained or downward pressure materialize, the exchange rate should be allowed to move flexibly as needed.

\section{Fiscal Policy}

13. Against the background of pressures for increasing spending ahead of the 2007 elections, the 2006 and 2007 budgets sought to achieve a balanced budget while giving increasing weight to the development spending needed for future growth. The bulk of the higher spending is geared to development expenditure (especially infrastructure), and mainly one-off increases to emphasize the temporary nature of the current record mineral revenue inflows. A large import content in most of these projects and weak budget execution capacity limiting the speed at which such spending takes place, will result in a manageable impact on inflation and medium-term sustainability, if the budget is

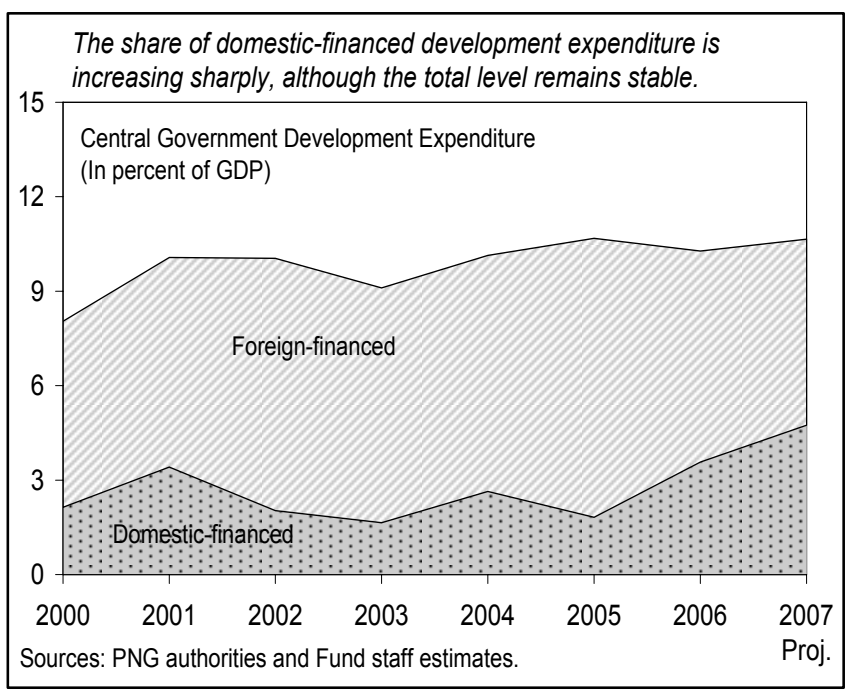
implemented as appropriated.

- $\quad$ The staff emphasized its concern that weak public expenditure management might result in leakages and nonpriority spending, which could lead to a build-up of demand and inflation pressure. In particular, the months ahead of the mid-2007 elections might lead to a further expenditure expansion, typical of previous election years. The authorities stressed that they did not wish to repeat the past mistake of pre-election spending excesses, particularly given the large size of revenues at stake. For this reason, the 2006-07 budgets had clearly-defined spending priorities of one-off development expenditure aligned closely with MTDS objectives. 
Box 3. Papua New Guinea: Reserve Adequacy and Costs of Carrying Reserves, 1980-2005 1/

Strong reserve accumulation since 2002 led to improvements in key vulnerability ratios...

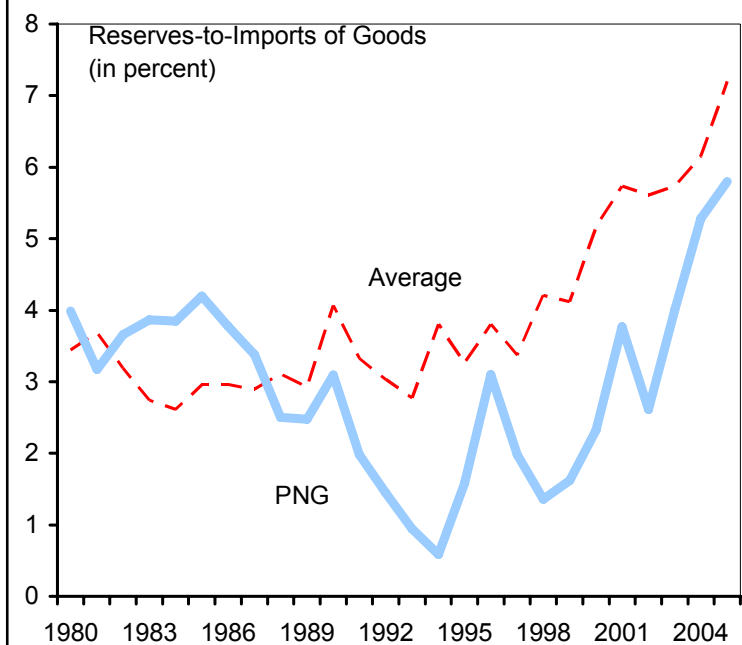

...but PNG has a lower debt coverage ratio compared with the comparator group.

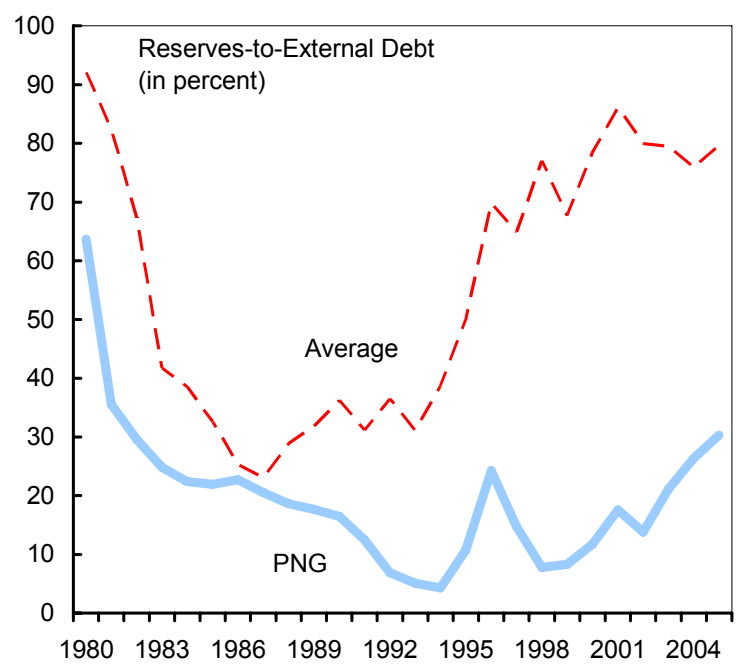

...in terms of broad money, PNG compares well with the overall sample...

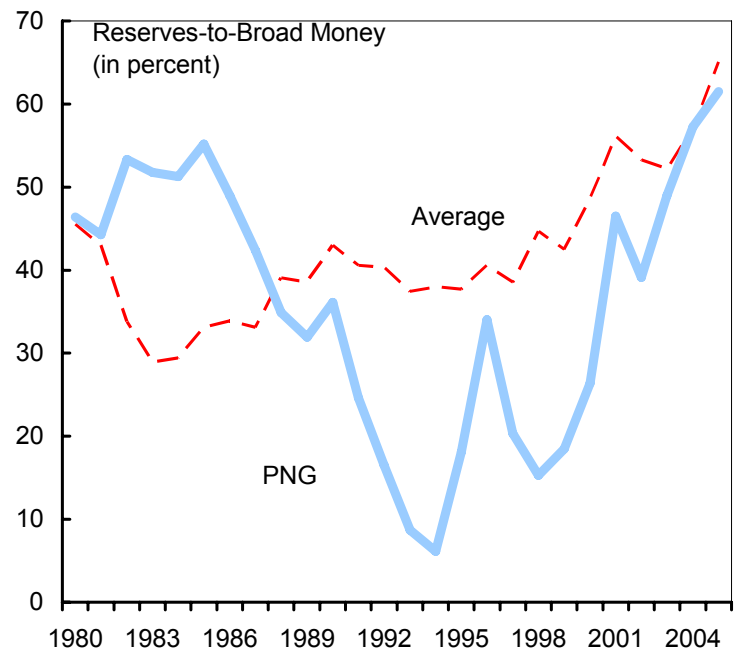

Net carrying costs of reserves peaked at 2.5 percent of GDP in 2003, declined to below 1 percent in 2005 and were negative in 2006.

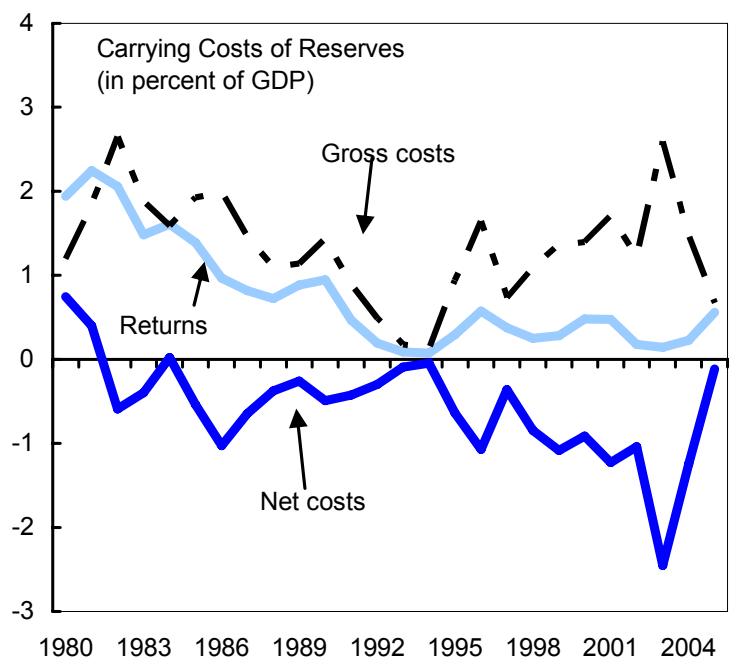

Sources: Papua New Guinea authorities, WEO, World Bank Development Indicators, and Fund staff estimates. 1/ The comparator group includes Barbados, Fiji, Jamaica, Samoa, and Trinidad and Tobago. 


\section{Box 4. Is Papua New Guinea Competitive?}

Papua New Guinea's ranking in the World Bank's ease-of-doing-business database compares relatively favorably with others in the region.

\begin{tabular}{|lcccccccc}
\hline \multicolumn{10}{|c|}{ Doing Business: Papua New Guinea and Comparators 1/ } \\
\hline
\end{tabular}

However, law and order and governance continue to be major disincentives to investment,

\begin{tabular}{|lcccccccc|}
\hline \multicolumn{10}{c|}{ Political Risk Points by Component } \\
\hline \multicolumn{1}{|c}{ Country } & Corruption & $\begin{array}{c}\text { Bureaucracy } \\
\text { Quality }\end{array}$ & $\begin{array}{c}\text { Ethnic } \\
\text { Tension }\end{array}$ & $\begin{array}{c}\text { Law and } \\
\text { Order }\end{array}$ & $\begin{array}{c}\text { Socioecon } \\
\text { Conditions }\end{array}$ & $\begin{array}{c}\text { Government } \\
\text { Stability }\end{array}$ & $\begin{array}{c}\text { Internal } \\
\text { Conflict }\end{array}$ \\
\hline Papua New Guinea & $\mathbf{1 . 0}$ & $\mathbf{2 . 0}$ & $\mathbf{2 . 0}$ & $\mathbf{2 . 5}$ & $\mathbf{3 . 5}$ & $\mathbf{6 . 5}$ & $\mathbf{9 . 5}$ \\
Indonesia & 2.5 & 2.0 & 2.0 & 3.0 & 6.5 & 6.5 & 9.0 \\
Bangladesh & 1.5 & 2.0 & 2.5 & 2.5 & 2.5 & 9.0 & 5.5 \\
Mongolia & 2.0 & 2.0 & 5.0 & 4.0 & 3.0 & 7.5 & 11.0 \\
Sri Lanka & 2.5 & 2.0 & 1.5 & 3.0 & 3.5 & 7.5 & 7.5 \\
\hline
\end{tabular}

Source: International Country Risk Guide, October 2006.

First 3 columns ranked 0-6, 2nd 4 columns ranked 0-12; the lower the number, the higher the risk.

along with other structural rigidities, including weak and costly basic utilities and transportation and communication infrastructure.

\begin{tabular}{|c|c|c|c|c|}
\hline \multicolumn{5}{|c|}{ Infrastructure Indicators, $2004^{1}$} \\
\hline & Fiji & Indonesia & $\begin{array}{l}\text { Lao } \\
\text { PDR }\end{array}$ & $\begin{array}{c}\text { Papua New } \\
\text { Guinea }\end{array}$ \\
\hline Air transport, freight (million tons per $\mathrm{km}$ ) & 75 & 434 & 2 & 23 \\
\hline Internet users (per 1,000 people) & 73 & 67 & 4 & 29 \\
\hline Telephone mainlines (per 1,000 people) & 122 & 46 & 13 & 12 \\
\hline Paved roads (in percent of total roads) & 49 & 58 & 14 & 4 \\
\hline Agricultural machinery (tractors per 100 hectares of arable land) & 2.82 & 0.45 & 0.11 & 0.52 \\
\hline Adult literacy rate (in percent) & 93 & 90 & 69 & 57 \\
\hline
\end{tabular}




\section{Box 4. Is Papua New Guinea Competitive (continued)?}

After a sharp rise in 2003-04, over the past year the kina appreciated less steeply against the U.S. dollar though it continued to rise significantly on a real effective basis.
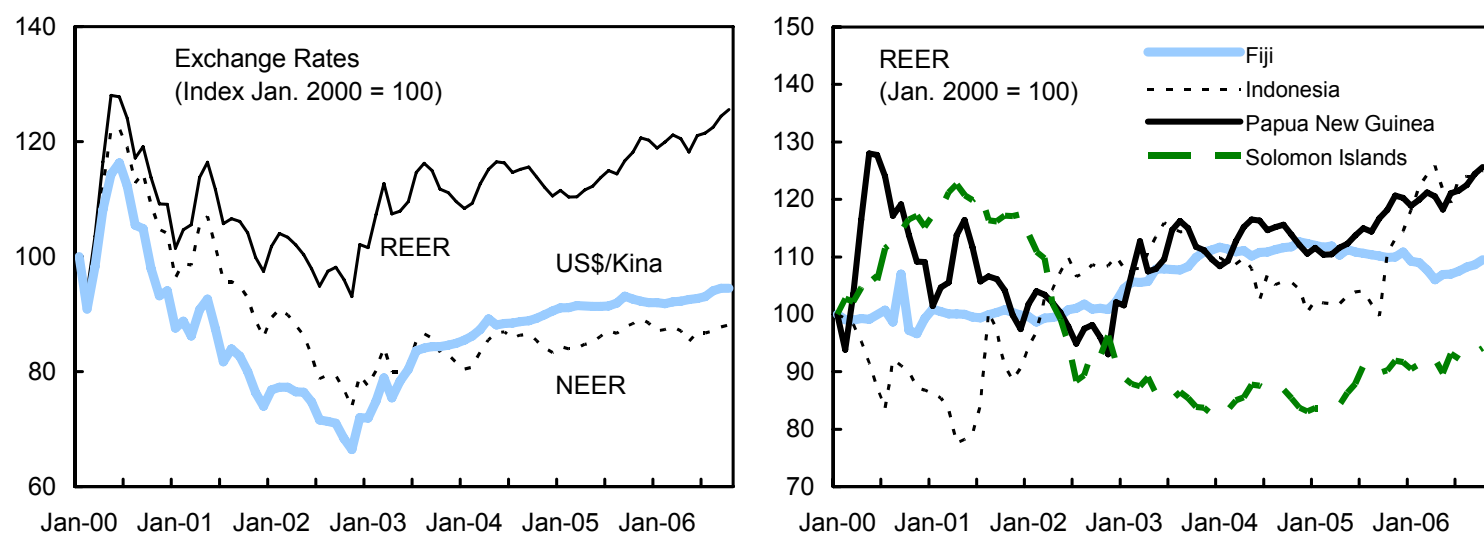

World export market shares increased on a total value basis... But largely reflected fuel-and-mineral price effects,
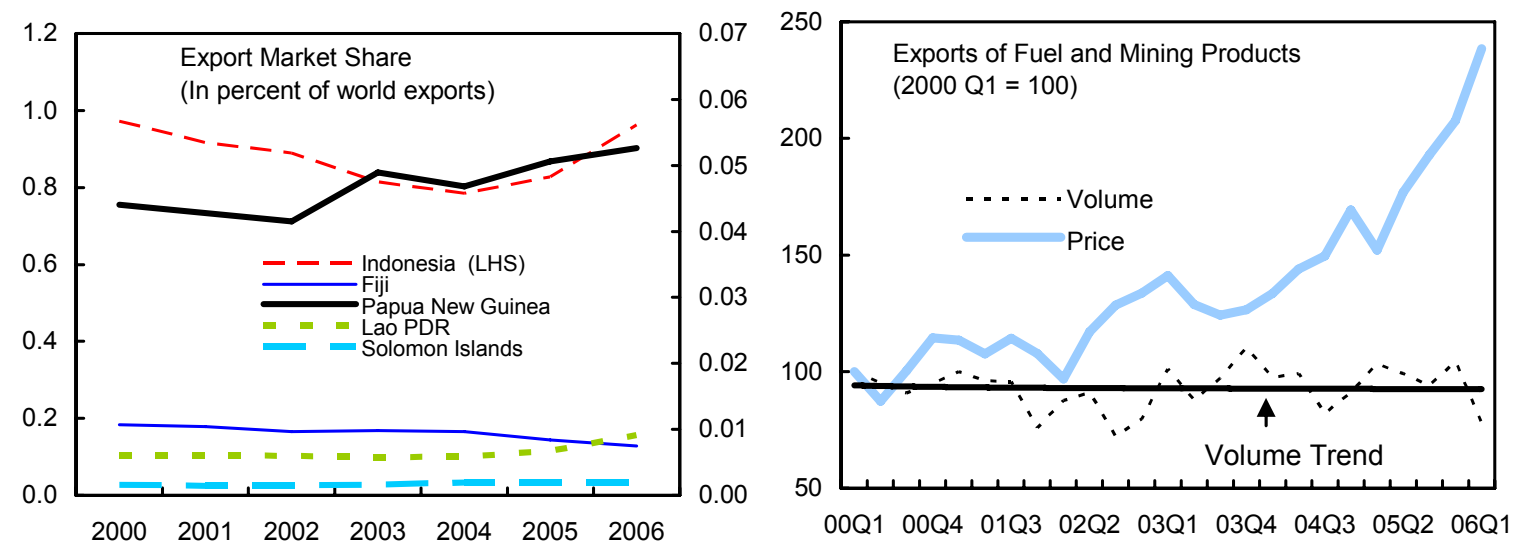

As export volumes show little or no improvement.
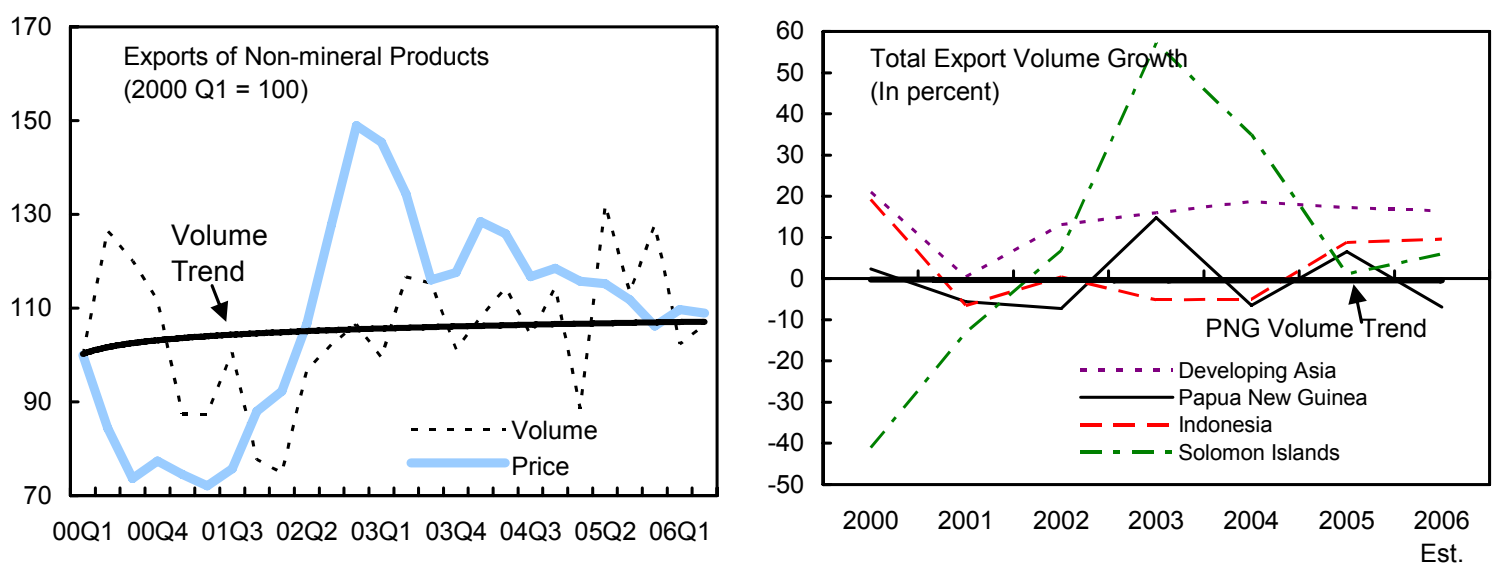

Sources: Papua New Guinea authorities; IMF Information Notice System and Direction of Trade Statistics; and Fund staff estimates. 
- $\quad$ Staff argued for using more of any expected revenue over-performance to pay down debt. Aside from external and domestic debt, this could also include covering the large unfunded government liability (about 10 percent of GDP) to the civil-servant superannuation fund. The authorities emphasized that their objective of pursuing deeper reduction of external debt under the MTDS was thwarted by costly penalties for early repayment, while paying down domestic debt was inconsistent with the desire to build a market for government securities. ${ }^{3}$ Regarding the superannuation fund, a reform strategy was already in place to fully cover new employees and to address the unfunded liability on an annual basis over time; however, they agreed to explore the staff's proposal in the future should revenue over-performance continue.

14. Given critical development needs, the staff welcomed the continuing shift in the expenditure mix toward public investment, particularly in infrastructure and human capital, and away from current expenditure.

- The staff noted with concern that the government had deferred action on the rightsizing initiative recommendations until mid-2007. The authorities agreed that reviving the public sector reform program should be a priority for the next government.

- $\quad$ Overall public sector employment has remained largely unchanged in recent years, and the wage bill was reduced relative to GDP, though it is still high (about 8 percent of GDP) relative to most comparators. In that light, the staff welcomed the authorities' intention to limit government workers' wage growth to productivity increases in the next round of public sector wage negotiations.

- In addition, the staff encouraged other steps to create further fiscal room, including reducing subsidies to public enterprises - about 0.7 percent of GDP in the 2006-07 budgets - in line with ongoing reforms, and assisting future development budgets by preparing costed plans for priority sectors consistent with the MTDS and integrated in the multi-year fiscal framework.

\section{However, past history indicates that in the absence of improved implementation} capacity, there is a risk that the large increase in development spending may not be efficiently spent. Leakages of funds deposited in trust accounts are a special concern given that accountability for many remains weak. ${ }^{4}$ To that end, the authorities and staff agreed on the immediate need to strengthen implementation of the existing donor-supported framework

\footnotetext{
${ }^{3}$ The penalties are mainly on loans from multilateral institutions.

${ }^{4}$ The estimated 150 trust funds accounts had an aggregate balance of 6.5 percent of GDP at end-2006, including about 3 percent of GDP set aside for future gas project investment.
} 
for public expenditure reform (the Public Expenditure Review and Rationalization project), including in particular:

- Urgently improving the monitoring and reporting of budget outcomes-including by applying sanctions to encourage compliance, expanding the system of financial controllers and auditors, closing trust accounts, and speeding up finalization of the Integrated Financial and Information Management System - and subjecting all expenditure to basic accountability procedures (including spending by major spending agencies, remaining trust fund accounts, district support grants, statutory authorities, and public enterprises);

- Strengthening budget execution, in particular for infrastructure and key services. The authorities noted their intention to process major contracts as efficiently and quickly as possible. They expressed interest in receiving technical assistance for improving budget execution, possibly through PFTAC;

- $\quad$ Clarifying the legal framework establishing responsibility at different government levels, subjecting provinces and local governments to basic controls and reporting standards, and reforming current unsustainable legal commitments for central government financing of provincial and local governments.

\section{While the existing medium-term fiscal strategy assisted the consolidation} achieved over the past several years, large mineral revenue inflows suggest a need for strengthening the strategy. The existing strategy targets budget balance and a decline in the debt-to-GDP ratio to 45 percent by 2009. However, given favorable debt dynamics, the medium-term debt-to-GDP target was achieved in 2006. Staff recommended a medium-term fiscal strategy that could better anchor fiscal sustainability, while leaving room for productive spending that would support higher sustained growth.

- $\quad$ Staff suggested that a revised medium-term fiscal framework that targets gradually improving nonmineral balances over the medium term - rather than continuing to target overall budget balance-would strengthen the ability to cope with the volatility and exhaustibility of mineral revenue and help prevent large yearly expenditure swings;

- $\quad$ The authorities could continue to cautiously spend any mineral revenue windfalls in future years for priority infrastructure and projects that enhance social welfare to the extent absorptive capacity permits, and use the remainder to further reduce debt;

- A more ambitious debt reduction strategy could lower the NPV debt-to-GDP ratio below the 30 percent threshold that classifies Papua New Guinea at a moderate risk by the end of the medium-term horizon. 
The authorities observed that they had already begun exploring possible changes to the fiscal strategy in anticipation of providing an updated framework for a new government following the elections. In that light, they expressed interest in giving further consideration to the staff's proposals in the months ahead.

17. As nonmineral revenue is already high relative to comparators, staff supported the authorities' emphasis on improving tax administration while preserving the revenue base. Guided by a three-year plan, the Internal Revenue Commission is pursuing continuing improvement in tax administration through better compliance and broadening of the tax base. The staff welcomed these measures, and emphasized the importance of quickly

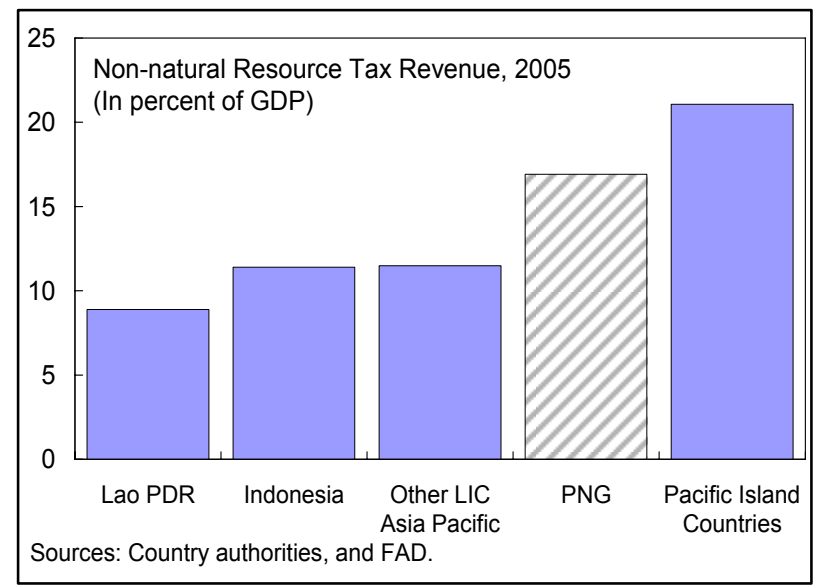
finalizing the draft Administration Act prepared with Fund technical assistance. It also suggested that a comprehensive review of the overall tax system would help ensure that new tax measures are consistent with the government's economy-wide priorities, the tax system promotes uniformity of treatment across all businesses, and the government receives a fair share of windfall profits from strong commodity prices.

\section{B. Structural Reform for Faster Growth and Development}

\section{Financial Sector Issues}

18. Given the importance of a developed and healthy financial sector for long-term growth, the recent rapid expansion of credit to the private sector is a welcome sign of re-intermediation. Private sector credit, although still low relative to comparators, has regained levels existing prior to the last economic downturn. Available data suggest that the distribution of the credit increase is relatively broad-based. Backward-looking indicators of financial sector soundness, such as nonperforming loans and return-on-assets, are favorable (Figure 5). In addition, three of the four major banks in Papua New Guinea are subsidiaries of established foreign banks, suggesting that underlying risks to the system are low. The authorities agreed with the staff's assessment, and noted that they would continue to monitor closely private sector credit growth for possible signs of increased sector concentration or a deterioration in credit quality.

\section{In addition, the authorities and staff agreed on other measures that would} further strengthen the financial sector. These include progressing rapidly on implementing MCM recommendations regarding bank supervision, a risk-based internal audit system, implementation of recently-enacted AML/CFT legislation, and strengthened internal management procedures. In addition, there is a need to reinforce supervision of 
superannuation funds, including passage of legislation now under consideration. Finally, the staff supported efforts underway to complete implementation of the steps needed for the creation of a secondary market for government securities.

20. New draft legislation would allow the Rural Development Bank to expand into microfinance without adequate oversight and accountability. The staff expressed concerns with this plan, not least given poor experience with development banks globally and within Papua New Guinea itself. The authorities acknowledged the risks and agreed that there is a need to adhere to basic financial sector supervision regulations, including the principle that all applications for a banking license, including microfinance operations, must comply with all due diligence and fit and proper criteria.

\section{Private Sector Development}

21. The authorities and staff agreed that for private nonmineral activity to become the main source of strong and sustainable economic growth and job creation, the investment environment needs considerable strengthening. While there have been some advances in recent years, the overall business environment remains difficult. Poor and costly transport and communications infrastructure, unreliable basic utilities, weak governance, high crime and weak prosecution, land issues, and little access to skilled labor constrain growth prospects. The staff observed that the budgeted increase in spending on infrastructure could measurably affect growth if efficiently executed.

22. The financial position of the large public utilities has improved in recent years and enterprises are now designing plans to improve service delivery, but concerns remain about the slow progress on services and continued need for fiscal subsidies. The staff recommended that, subject to the still incomplete appropriate regulatory framework being put in place, parallel actions should be taken such as privatization, opening sectors to competition, or private minority shares to introduce shareholder oversight. The authorities noted that they have no plans to advance privatization. The current strategy focuses on costcutting, rationalization and enhancement of services, and the possible use of privatepartnership arrangements as a source of expertise and capital.

\section{Other Issues}

23. Papua New Guinea maintains one of the least restrictive trade regimes in the region. In 2006, the authorities completed the seven-year tariff reform program launched in 1999 compressing the tariff structure to four rates, with the zero rate applicable on three quarters of commodities. However, the 2007 budget introduced new exceptions by raising tariffs by 5-25 percent on three imports (canned beans and tuna, and soft drinks) to protect local industry. The staff expressed concerns with the backtracking on tariff reform and urged redressing these slippages as quickly as possible. The authorities explained that the increases were temporary pending a comprehensive review of tariff policy. 
24. Progress by the Auditor General's office in completing public account audits with greater timeliness is welcomed, along with the improved compliance by budget agencies in providing data. The staff suggested that broader accessibility of the general public to completed audits — now available through 2005-would help strengthen transparency and accountability. The authorities noted that plans were also underway to further improve timeliness and to expand the scope of budget audits to include an assessment of governance issues.

25. Although data provision is generally adequate for surveillance purposes, the authorities agreed that shortcomings in quality, coverage, and timeliness continue to hinder effective monitoring of macroeconomic developments. The poor condition of fiscal, national accounts, and balance of payments data also add to the lack of transparency and accountability within the public sector. The authorities welcomed the recommendations of the recent STA multi-sector mission for strengthening the statistical framework and are developing a plan for implementing the recommendations and rehabilitating the National Statistical Office.

\section{StafF ApPraisal}

26. Papua New Guinea has made good progress in achieving macroeconomic stability since 2002. The fiscal consolidation set in motion at that time, along with supportive monetary policy and favorable export commodity prices, have led to the fourth year of real economic growth and low inflation. However, reflecting earlier years of poor economic management and political instability, per capita income is little changed since independence, and development needs remain high. The main challenge facing Papua New Guinea is maintaining macroeconomic stability in the short term, especially given increased downside risks. An improved investment environment is also needed to encourage faster growth in the longer term that would reduce poverty and unemployment, and close the performance gap with comparator countries.

27. The current monetary policy stance seeks to maintain low inflation. With upward risks for inflation over the next year, including from increases in government spending, the authorities should be prepared to tighten monetary policy should signs of inflation pressure emerge.

28. The managed float exchange rate policy is appropriate. Given the temporary nature of the current large mineral revenue inflows, the need to guard against the loss of nonmineral sector competitiveness and accumulation of reserves are a pragmatic response. However, additional flexibility should be shown in the face of sustained upward pressure or should downward pressure materialize.

29. The 2006 supplementary budgets and 2007 budget are appropriately focused on one-off development expenditure given the temporary nature of the current large 
mineral revenue inflows. The clearly defined priorities reflected in the decrease in recurrent spending and debt, and increase in development expenditure are welcomed. However, the potential size of the spending increase and the risks that spending will not be used as appropriated are significant concerns, especially given weak implementation capacity and the history of misappropriation of funds and pre-election spending excesses. To address these concerns, the enforcement of the monitoring and reporting of budget outcomes should be considerably strengthened and all major spending agencies should be subject to basic accountability procedures. The staff also urges moving rapidly to resume implementation of the right-sizing initiative to streamline public spending and welcomes plans to limit wage increases to productivity increases. Greater debt reduction is advocated, especially if further windfall revenue materializes, such as covering the large unfunded liability to the civil servant superannuation fund. In addition, preservation of the nonmineral revenue base would be a critical support for long-term fiscal sustainability.

30. The recent expansion of credit to the private sector is a welcome sign, given the importance of a developed financial sector for long-term growth. The overall financial sector appears sound. However, the authorities are urged to follow through with recommendations to expand supervision to non-banking financial institutions, tighten propriety controls at the central bank, and complete implementation of AML/CFT legislation. Plans to expand the development bank into microfinance without adequate oversight are a concern and should be reversed.

31. Little progress has been made on the underlying structural constraints holding back private sector activity and more rapid medium-term growth. While the financial position of public utility monopolies has improved, services remain costly and unreliable. The necessary regulatory framework should be quickly finalized as a first step to introduce competition to the public enterprise sector. Rapid progress is also needed to improve the transport and communications infrastructure and strengthen governance and law enforcement.

32. Although data provision is generally adequate for surveillance purposes, major shortcomings in quality and timeliness continue to affect monitoring of macroeconomic developments. The authorities' intention to overhaul the main statistical framework is welcomed. Implementation of the STA mission's recommendations should begin without delay.

33. The staff recommends that the next Article IV consultation be held on the standard 12-month cycle. 
Table 1. Papua New Guinea: Millennium Development Goals Progress, 1990 - 2004

\begin{tabular}{llllll}
\hline & 1990 & 1995 & 1998 & 2001 & 2004 \\
\hline
\end{tabular}

Goal 1: Eradicate extreme poverty and hunger

Target 1: Halve, between 1990 and 2015, the proportion of people whose income is less than $\$ 1$ a day

Target 2: Halve, between 1990 and 2015, the proportion of people who suffer from hunger Income share held by lowest $20 \%$

Poverty headcount, national (\% of population)

Prevalence of underweight in children (under five years of age)

$\begin{array}{ccccc}. . & 5 & . . & . . & . . \\ . . & 38 & . . & . . & . . \\ . . & . . & 15 & . . & 13\end{array}$

Goal 2: Achieve universal primary education

Target 3: Ensure that, by 2015, children everywhere, boys and girls alike, will be able to complete a full course of primary schooling

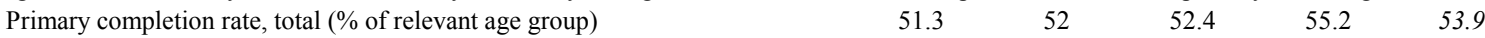

Persistence to grade 5 , total ( $\%$ of cohort)

Youth literacy rate (\% ages $15-24)$

$\begin{array}{llll}69 & . . & 68 & 69\end{array}$

$\begin{array}{lllll}69 & . . & . . & . . & 67\end{array}$

Goal 3: Promote gender equality and empower women

Target 4: Eliminate gender disparity in primary and secondary education preferably by 2005 and in all levels of education no later than 2015 Proportion of seats held by women in national parliament $(\%)$

Ratio of girls to boys in primary and secondary education $(\%)$

Ratio of young literate females to males (\% ages 15-24)

Share of women employed in the nonagricultural sector (\%)

$\begin{array}{ccccc}0 & . . & 2 & 2 & 1 \\ 80.3 & . . & 88.9 & 88.1 & 87 \\ 83.9 & . . & . . & . . & 92.7 \\ 20 & 26 & 30 & 33 & 35\end{array}$

Goal 4: Reduce child mortality

Target 5: Reduce by two-thirds, between 1990 and 2015, the under-five mortality rate

Immunization, measles ( $\%$ of children ages 12-23 months)

Infant mortality rate (per 1,000 live births)

Under 5 mortality rate (per 1,000)

$67 \quad 75$

Goal 5: Improve maternal health

95

Target 6: Reduce by three-quarters, between 1990 and 2015, the maternal mortality ratio Births attended by skilled health staff ( $\%$ of total)

Maternal mortality ratio (modeled estimate, per 100,000 live births)

$53.2 \quad+. \quad 41$

Goal 6: Combat HIV/AIDS, malaria, and other diseases

Target 7: Have halted by 2015 and begun to reverse the spread of HIV/AIDS

Prevalence of HIV, total ( $\%$ of population aged 15-49)

Target 8: Have halted by 2015 and begun to reverse the incidence of malaria and other major diseases

Contraceptive prevalence rate (\% of women ages $15-49)$

Incidence of tuberculosis (per 100,000 people)

Tuberculosis cases detected under DOTS (\%)

$\begin{array}{cc}. . & 26 \\ 267 & . .\end{array}$

$\begin{array}{ccc}53.2 & . . & 41 \\ . . & . . & 300\end{array}$

Goal 7: Ensure environmental sustainability

Target 9: Integrate the principles of sustainable development into country policies and program and reverse the loss of environmental resources Forest area (\% of total land area)

Nationally protected areas (\% of total land area)

$\begin{array}{lllll}70 & . . & . . & 67 & 65\end{array}$

Target 10: Halve, by 2015 , the proportion of people without sustainable access to safe drinking water and basic sanitation

Access to an improved water source (\% of population)

$\begin{array}{llll}39 & \text {.. } & \text {.. } & 39\end{array}$

Target 11: Have achieved, by 2020, a significant improvement in the lives of at least 100 million slum dwellers

Access to improved sanitation (\% of population)

$\mathrm{CO} 2$ emissions (metric tons per capita)

$\begin{array}{ccccc}44 & . . & . . & . . & 44 \\ 0.6 & 0.5 & 0.5 & 0.5 & . .\end{array}$

Target 12: Various

Goal 8: Develop a global partnership for development

Aid per capita (current US\$)

Debt service (\% of exports)

Fixed line and mobile phone subscribers (per 1,000 people)

Internet users (per 1,000 people)

Personal computers (per 1,000 people)

\section{General Indicators}

Fertility rate, total (births per woman)

GNI per capita, Atlas method (current US\$)

GNI, Atlas method (current US\$) (billions)

Gross capital formation ( $\%$ of GDP)

Life expectancy at birth, total (years)

Literacy rate, adult total ( $\%$ of people ages 15 and above)

Population, total (millions)

Trade (\% of GDP)

$\begin{array}{ccccc}100.4 & 79.2 & 71.5 & 37.5 & 46.1 \\ 18 & 10 & 8 & 7 & . . \\ 7.3 & 9.3 & 12.4 & 13.4 & 19.1 \\ 0 & 0 & 2.4 & 9.2 & 29.5 \\ . . & . . & 39.5 & 55.4 & 63.6 \\ & & & & \\ 5.1 & 4.8 & 4.6 & 4.1 & 3.9 \\ 830 & 1060 & 810 & 560 & 550 \\ 3.4 & 5 & 4.1 & 3 & 3.2 \\ 24.4 & 22.1 & 17.9 & . . & . . \\ 52.3 & 53.4 & 53.8 & 55.2 & 56 \\ 56.6 & . . & . . & . . & 57.3 \\ 4.1 & 4.7 & 5.1 & 5.4 & 5.8 \\ 89.6 & 105.6 & 96.5 & 132.2 & 125.3\end{array}$

Source: World Development Indicators database, September 2006.

Figures in italics refer to periods other than those specified. 
Table 2. Papua New Guinea: Selected Economic Indicators, 2002-07

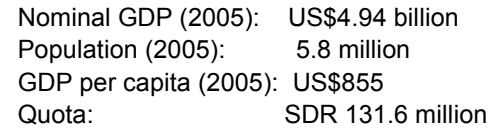

\begin{tabular}{|c|c|c|c|c|c|c|}
\hline & 2002 & 2003 & 2004 & 2005 & $\begin{array}{r}2006 \\
\text { Est. }\end{array}$ & $\begin{array}{r}2007 \\
\text { Proj. }\end{array}$ \\
\hline \multicolumn{7}{|l|}{ Real sector (percent change) } \\
\hline Real GDP growth 1/ & -0.2 & 2.2 & 2.7 & 3.3 & 3.7 & 4.3 \\
\hline Mineral & -15.9 & 2.8 & 0.3 & 5.0 & 0.2 & 6.2 \\
\hline Nonmineral & 2.5 & 2.1 & 3.1 & 3.1 & 4.1 & 4.0 \\
\hline CPI (annual average) & 11.8 & 14.7 & 2.1 & 1.7 & 3.5 & 4.3 \\
\hline \multicolumn{7}{|l|}{ Central government operations (percent of GDP) } \\
\hline Revenue and grants & 27.8 & 29.1 & 34.1 & 34.2 & 36.1 & 32.1 \\
\hline Expenditure and net lending & 31.9 & 30.3 & 32.4 & 30.6 & 29.7 & 30.1 \\
\hline Overall balance, cash basis (including grants) 2/ & -5.3 & -1.8 & 0.0 & 4.1 & 6.4 & 2.1 \\
\hline Domestic financing (net) 3/ & 6.1 & 4.0 & 1.8 & -2.7 & -5.2 & -1.6 \\
\hline External financing (net) & -0.9 & -2.1 & -1.8 & -1.4 & -1.3 & -0.5 \\
\hline Nonmineral balance $2 /$ & -8.5 & -6.4 & -6.3 & -4.3 & -6.5 & -7.7 \\
\hline Central government debt (percent of GDP) & 71.7 & 63.6 & 60.0 & 47.3 & 39.2 & 39.8 \\
\hline \multicolumn{7}{|l|}{ Money and credit (end-period percentage change) } \\
\hline Domestic credit & 30.7 & -7.1 & 0.7 & 8.6 & 5.4 & 3.6 \\
\hline Net credit to government & 114.4 & -8.3 & 3.2 & -13.9 & -37.3 & -46.3 \\
\hline Credit to the private sector & 1.4 & -4.1 & 0.9 & 23.7 & 27.9 & 16.5 \\
\hline Broad money & 7.3 & -4.4 & 14.8 & 29.5 & 33.0 & 13.0 \\
\hline Interest rate (182-day T-bills; period average) & 10.9 & 18.7 & 3.1 & 3.8 & 3.4 & $\ldots$ \\
\hline \multicolumn{7}{|l|}{ Balance of payments (millions of U.S. dollars) } \\
\hline Exports, f.o.b. & 1,646 & 2,153 & 2,554 & 3,278 & 4,379 & 4,455 \\
\hline Imports, c.i.f. & $-1,302$ & $-1,435$ & $-1,794$ & $-2,462$ & $-2,895$ & $-3,123$ \\
\hline Current account (including grants) & -31 & 159 & 88 & 190 & 421 & 140 \\
\hline (In percent of GDP) & -1.0 & 4.5 & 2.2 & 3.8 & 7.4 & 2.5 \\
\hline Overall balance & -101 & 187 & 206 & 161 & 686 & 124 \\
\hline \multicolumn{7}{|l|}{ Reserves and external debt (end-period; millions of U.S. dollars) } \\
\hline Net international reserves & 223 & 399 & 599 & 765 & 1,450 & 1,575 \\
\hline (In months of nonmining imports, c.i.f.) & 3.0 & 4.3 & 5.5 & 5.2 & 8.3 & 8.7 \\
\hline (In months of goods and services imports) & 2.0 & 2.7 & 2.8 & 2.4 & 3.9 & 3.9 \\
\hline Public external debt-service-ratio (percent of exports) 4/ & 7.9 & 7.5 & 8.7 & 6.0 & 3.5 & 2.5 \\
\hline Public external debt-to-GDP ratio (in percent) 4/ & 54.2 & 42.9 & 36.8 & 25.3 & 20.7 & 20.6 \\
\hline \multicolumn{7}{|l|}{ Exchange rates } \\
\hline US\$/kina (period-average) & 0.2573 & 0.2814 & 0.3104 & 0.3223 & 0.3274 & $\ldots$ \\
\hline US\$/kina (end-period) & 0.2488 & 0.3000 & 0.3200 & 0.3230 & 0.3300 & $\ldots$ \\
\hline Nominal GDP (millions of kina) & 11,656 & 12,567 & 12,652 & 15,339 & 17,269 & 17,633 \\
\hline
\end{tabular}

Sources: Data provided by the Papua New Guinea authorities; and Fund staff estimates and projections.

1/ Based on new official national account estimates (1998 prices).

2/ Measured from below-the-line in the fiscal accounts.

$3 /$ Includes changes in check float.

4/ Includes central government, central bank external debt, and statutory authorities. 
Table 3. Papua New Guinea: Summary of Central Government Operations, 2003-07

\begin{tabular}{|c|c|c|c|c|c|c|c|}
\hline & \multirow[t]{2}{*}{2003} & \multirow[t]{2}{*}{2004} & \multirow[t]{2}{*}{2005} & \multicolumn{2}{|c|}{2006} & \multicolumn{2}{|c|}{2007} \\
\hline & & & & Budget 1/ & Est. & Budget & Proj. \\
\hline Revenue and grants & 29.1 & 34.1 & 34.2 & 35.3 & 36.1 & 30.3 & 32.1 \\
\hline Revenue & 23.2 & 27.4 & 26.2 & 29.5 & 30.3 & 25.3 & 27.2 \\
\hline Tax revenue & 21.3 & 25.4 & 24.4 & 27.4 & 28.2 & 23.4 & 25.4 \\
\hline Mineral taxes & 4.0 & 5.8 & 7.5 & 11.4 & 11.7 & 7.5 & 9.0 \\
\hline Nonmineral taxes & 17.3 & 19.6 & 16.9 & 16.0 & 16.5 & 15.9 & 16.4 \\
\hline Nontax revenue & 1.8 & 2.0 & 1.8 & 2.2 & 2.2 & 1.9 & 1.7 \\
\hline Grants & 5.9 & 6.7 & 8.0 & 5.8 & 5.8 & 5.0 & 5.0 \\
\hline Total expenditure and net lending & 30.3 & 32.4 & 30.6 & 34.7 & 29.7 & 30.5 & 30.1 \\
\hline Recurrent expenditure & 21.3 & 22.4 & 19.9 & 19.4 & 19.4 & 19.4 & 19.4 \\
\hline National departments & 9.5 & 12.5 & 12.0 & 11.3 & 11.3 & 11.2 & 11.2 \\
\hline Salaries and wages & 4.9 & 5.4 & 4.5 & 5.0 & 5.0 & 4.6 & 4.6 \\
\hline Arrears payments & 0.1 & 0.3 & 0.6 & 0.4 & 0.4 & 0.3 & 0.3 \\
\hline Goods and services & 4.2 & 5.9 & 5.9 & 5.2 & 5.2 & 5.7 & 5.7 \\
\hline Other & 0.2 & 0.8 & 0.9 & 0.6 & 0.6 & 0.6 & 0.6 \\
\hline Provinces & 4.7 & 5.4 & 4.4 & 4.4 & 4.4 & 4.2 & 4.2 \\
\hline Salaries and wages & 4.0 & 4.7 & 3.5 & 3.6 & 3.6 & 3.3 & 3.3 \\
\hline Goods and services & 0.5 & 0.5 & 0.4 & 0.3 & 0.3 & 0.4 & 0.4 \\
\hline Conditional grants/Bougainville 2/ & 0.2 & 0.2 & 0.5 & 0.5 & 0.5 & 0.6 & 0.6 \\
\hline Statutory authorities & 1.6 & 1.6 & 1.3 & 1.2 & 1.2 & 1.3 & 1.3 \\
\hline Interest & 5.5 & 2.9 & 2.2 & 2.5 & 2.5 & 2.7 & 2.7 \\
\hline Domestic & 4.2 & 1.9 & 1.4 & 1.9 & 1.9 & 2.0 & 2.0 \\
\hline Foreign & 1.3 & 1.0 & 0.8 & 0.7 & 0.7 & 0.7 & 0.7 \\
\hline Development expenditures and net lending & 9.0 & 10.1 & 10.7 & 15.3 & 10.3 & 11.0 & 10.6 \\
\hline Development expenditure & 9.1 & 10.1 & 10.7 & 14.7 & 10.3 & 11.1 & 10.7 \\
\hline Foreign financed & 7.5 & 7.5 & 8.9 & 6.7 & 6.7 & 5.9 & 5.9 \\
\hline Project grants & 5.9 & 6.7 & 8.0 & 5.8 & 5.8 & 5.0 & 5.0 \\
\hline Project concessional loans & 1.1 & 0.6 & 0.9 & 0.9 & 0.9 & 0.9 & 0.9 \\
\hline Nonconcessional loans & 0.4 & 0.2 & 0.0 & 0.0 & 0.0 & 0.0 & 0.0 \\
\hline Domestically funded & 1.6 & 2.6 & 1.8 & 8.0 & 3.6 & 5.2 & 4.7 \\
\hline Net lending $3 /$ & -0.1 & -0.1 & 0.0 & 0.6 & 0.0 & 0.0 & 0.0 \\
\hline Overall balance (from above the line) & -1.2 & 1.7 & 3.6 & 0.6 & 6.4 & -0.2 & 2.1 \\
\hline Residual deficit & -0.6 & -1.7 & 0.5 & 0.0 & 0.0 & 0.0 & 0.0 \\
\hline Overall balance (from below the line) & -1.8 & 0.0 & 4.1 & 0.6 & 6.4 & -0.2 & 2.1 \\
\hline Financing & 1.8 & 0.0 & -4.1 & -0.6 & -6.4 & 0.2 & -2.1 \\
\hline External financing (net) & -2.1 & -1.8 & -1.4 & -1.3 & -1.3 & -0.5 & -0.5 \\
\hline Disbursements & 1.5 & 1.4 & 0.9 & 0.9 & 0.9 & 0.9 & 0.9 \\
\hline Amortization 4/ & -3.6 & -3.2 & -2.3 & -2.2 & -2.2 & -1.4 & -1.4 \\
\hline Domestic financing (net) & 4.0 & 1.8 & -2.7 & 0.7 & -5.2 & 0.7 & -1.6 \\
\hline Banking sector & -0.9 & 0.3 & -1.2 & $\ldots$ & -2.5 & 0.0 & -1.9 \\
\hline Nonbanks & 4.5 & 0.2 & -1.5 & $\ldots$ & -2.7 & 0.0 & 0.2 \\
\hline Float & 0.0 & 1.0 & 0.0 & $\ldots$ & 0.0 & 0.0 & 0.0 \\
\hline Asset sales & 0.3 & 0.2 & 0.0 & $\ldots$ & 0.0 & 0.0 & 0.0 \\
\hline \multicolumn{8}{|l|}{ Memoranda items: } \\
\hline Nonmineral overall balance (below the line) & -6.4 & -6.3 & -4.3 & $\ldots$ & -6.5 & -8.6 & -7.7 \\
\hline Nonmineral primary balance & -0.9 & -3.4 & -2.1 & $\ldots$ & -4.0 & -5.9 & -5.0 \\
\hline Total central govt. gross debt (\% of GDP) & 63.6 & 60.0 & 47.3 & 39.2 & 39.2 & $\ldots$ & 39.8 \\
\hline Nominal GDP (in millions of kina) & 12,567 & 12,652 & 15,339 & 17,269 & 17,269 & 17,633 & 17,633 \\
\hline
\end{tabular}

Sources: Data provided by the Papua New Guinea authorities; and Fund staff estimates and projections.

1/ Supplementary budget passed in August 2006, plus November appropriation bill.

2/ Since 2005, this includes transfers to Bougainville.

3/ In 2005-06, the authorities treat savings for a future acquisition of an equity participations in the PNG gas project as an expenditure. Under IMF's GFS standards, these are treated as savings below the line. These savings are then used in 2006 and the transaction is registered below the line under nonbanks domestic financing. A memo item shows IMF staff projections according to the authorities' treatment.

$4 /$ In 2006, includes budget expenditure for loan repayment. 
Table 4. Papua New Guinea: Summary Accounts of the Banking System, 2002-07

\begin{tabular}{|c|c|c|c|c|c|c|}
\hline & 2002 & 2003 & 2004 & 2005 & $\begin{array}{r}2006 \\
\text { Est. }\end{array}$ & $\begin{array}{l}2007 \\
\text { Proj. }\end{array}$ \\
\hline Bank of Papua New Guinea & \multicolumn{6}{|c|}{ (In millions of kina; end of period) } \\
\hline Net foreign assets & 909 & 1,322 & 1,869 & 2,367 & 4,395 & 4,968 \\
\hline Foreign assets & 1,377 & 1,743 & 2,072 & 2,368 & 4,396 & 4,969 \\
\hline Foreign liabilities & 468 & 421 & 203 & 1 & 1 & 1 \\
\hline Net domestic assets & -239 & -653 & -998 & $-1,432$ & $-3,343$ & $-3,799$ \\
\hline Domestic credit & 676 & 308 & 7 & -502 & $-1,104$ & $-1,489$ \\
\hline Net credit to government & 550 & 243 & -26 & -538 & $-1,140$ & $-1,525$ \\
\hline Claims & 663 & 350 & 79 & 108 & 174 & 249 \\
\hline Central government deposits & 114 & 106 & 105 & 646 & 1,314 & 1,773 \\
\hline Credit to other sectors & 126 & 64 & 34 & 36 & 36 & 36 \\
\hline Other items net & -915 & -961 & $-1,006$ & -929 & $-2,238$ & $-2,311$ \\
\hline Reserve money & 669 & 669 & 871 & 935 & 1,052 & 1,168 \\
\hline Currency in circulation & 472 & 512 & 531 & 606 & 637 & 651 \\
\hline Deposits of other depository corporations & 192 & 153 & 332 & 322 & 407 & 509 \\
\hline Other deposits & 5 & 4 & 8 & 8 & 8 & 8 \\
\hline Monetary Survey & \multicolumn{6}{|c|}{ (In millions of kina; end of period) } \\
\hline Net foreign assets & 1,421 & 1,621 & 2,165 & 2,929 & 4,665 & 5,243 \\
\hline Net domestic assets & 2,148 & 1,789 & 1,750 & 2,141 & 2,077 & 2,375 \\
\hline Domestic credit & 3,277 & 3,046 & 3,066 & 3,329 & 3,507 & 3,635 \\
\hline Net credit to central government & 1,366 & 1,253 & 1,293 & 1,114 & 698 & 375 \\
\hline Claims on other sectors & 1,911 & 1,793 & 1,773 & 2,215 & 2,809 & 3,260 \\
\hline Claims on the private sector & 1,780 & 1,707 & 1,724 & 2,133 & 2,727 & 3,178 \\
\hline Other items, net & $-1,129$ & $-1,256$ & $-1,316$ & $-1,188$ & $-1,430$ & $-1,260$ \\
\hline Broad money & 3,569 & 3,410 & 3,915 & 5,069 & 6,742 & 7,619 \\
\hline Narrow money & 1,599 & 1,707 & 2,232 & 3,017 & 3,705 & 4,217 \\
\hline Currency outside banks & 363 & 388 & 400 & 445 & 524 & 587 \\
\hline Demand deposits & 1,236 & 1,319 & 1,832 & 2,572 & 3,181 & 3,631 \\
\hline \multirow[t]{2}{*}{ Quasi money } & 1,971 & 1,704 & 1,683 & 2,052 & 3,037 & 3,401 \\
\hline & \multicolumn{6}{|c|}{ (Annual percentage change) } \\
\hline Net foreign assets & -12.4 & 14.1 & 33.5 & 35.3 & 59.3 & 12.4 \\
\hline Net domestic assets & 26.0 & -16.7 & -2.2 & 22.3 & -3.0 & 14.4 \\
\hline Net domestic credit & 30.7 & -7.1 & 0.7 & 8.6 & 5.4 & 3.6 \\
\hline Of which: Private sector & 1.4 & -4.1 & 0.9 & 23.7 & 27.9 & 16.5 \\
\hline Broad money & 7.3 & -4.4 & 14.8 & 29.5 & 33.0 & 13.0 \\
\hline \multicolumn{7}{|l|}{ Memoranda items: } \\
\hline Reserve money (percentage change) & 13.5 & -0.1 & 30.2 & 7.4 & 12.5 & 11.0 \\
\hline Gross international reserves (in millions of US dollars) & 339 & 523 & 663 & 765 & 1,451 & 1,575 \\
\hline Broad money velocity & 3.3 & 3.7 & 3.2 & 3.0 & 2.6 & 2.3 \\
\hline Nominal nonmineral GDP/Broad money & 2.7 & 3.0 & 2.6 & 2.3 & 1.8 & 1.7 \\
\hline
\end{tabular}

Sources: Data provided by the Papua New Guinea authorities; and Fund staff estimates and projections. 
Table 5. Papua New Guinea: Balance of Payments, 2002-07

(In millions of U.S. dollars)

\begin{tabular}{|c|c|c|c|c|c|c|}
\hline & 2002 & 2003 & 2004 & 2005 & $\begin{array}{r}2006 \\
\text { Est. }\end{array}$ & $\begin{array}{r}2007 \\
\text { Proj. }\end{array}$ \\
\hline Current account balance & -31 & 159 & 88 & 190 & 421 & 140 \\
\hline Mineral & 473 & 728 & 793 & 1,039 & 1,523 & 1,204 \\
\hline Nonmineral & -503 & -569 & -705 & -849 & $-1,103$ & $-1,064$ \\
\hline Trade balance & 344 & 718 & 760 & 816 & 1,484 & 1,332 \\
\hline Exports (f.o.b.) & 1,646 & 2,153 & 2,554 & 3,278 & 4,379 & 4,455 \\
\hline Mineral & 1,228 & 1,635 & 1,863 & 2,467 & 3,419 & 3,368 \\
\hline Nonmineral & 417 & 518 & 690 & 811 & 961 & 1,087 \\
\hline Imports (c.i.f.) & $-1,302$ & $-1,435$ & $-1,794$ & $-2,462$ & $-2,895$ & $-3,123$ \\
\hline Mineral & -397 & -325 & -482 & -693 & -795 & -953 \\
\hline Nonmineral & -905 & $-1,109$ & $-1,312$ & $-1,769$ & $-2,101$ & $-2,171$ \\
\hline Services & -345 & -388 & -485 & -674 & -832 & -936 \\
\hline Income & -226 & -407 & -368 & -386 & -584 & -564 \\
\hline Current Transfers & 197 & 235 & 182 & 434 & 353 & 308 \\
\hline Capital and financial account balance & -104 & -23 & 35 & 0 & 265 & -16 \\
\hline Direct investment & 19 & 97 & 26 & 68 & 128 & 107 \\
\hline Other investment & -123 & -120 & 10 & -68 & 137 & -123 \\
\hline Medium- and long-term loan disbursements & -154 & -151 & -213 & -175 & -143 & -103 \\
\hline Commercial banks & -33 & -60 & -1 & -87 & 94 & -4 \\
\hline Other & 63 & 90 & 224 & 194 & 186 & -16 \\
\hline Net errors and omissions & 34 & 52 & 82 & -29 & 0 & 0 \\
\hline Overall balance & -101 & 187 & 206 & 161 & 686 & 124 \\
\hline Financing & 101 & -187 & -206 & -161 & -686 & -124 \\
\hline Reserve assets & 101 & -184 & -140 & -102 & -686 & -124 \\
\hline Use of IMF credit & 0 & -6 & -62 & -59 & 0 & 0 \\
\hline Purchases & 0 & 0 & 0 & 0 & 0 & 0 \\
\hline Repurchases & 0 & -6 & -62 & -59 & 0 & 0 \\
\hline Other foreign liabilities & 0 & 3 & -4 & 0 & 0 & 0 \\
\hline \multicolumn{7}{|l|}{ Memorandum items: } \\
\hline Current account (in percent of GDP) & -1.0 & 4.5 & 2.2 & 3.8 & 7.4 & 2.5 \\
\hline Mineral & 15.8 & 20.6 & 20.2 & 21.0 & 26.9 & 21.1 \\
\hline Nonmineral & -16.8 & -16.1 & -17.9 & -17.2 & -19.5 & -18.7 \\
\hline \multicolumn{7}{|l|}{ Net international reserves (end-year) } \\
\hline In millions of U.S. dollars & 223 & 399 & 599 & 765 & 1,450 & 1,575 \\
\hline \multicolumn{7}{|l|}{ Gross official reserves (end-year) } \\
\hline In millions of U.S. dollars & 339 & 523 & 663 & 765 & 1,451 & 1,575 \\
\hline In months of nonmineral imports & 4.5 & 5.7 & 6.1 & 5.2 & 8.3 & 8.7 \\
\hline In months of imports of goods and nonfactor services & 2.0 & 2.7 & 2.8 & 2.4 & 3.9 & 3.9 \\
\hline Public external debt-service-exports ratio (in percent) & 7.9 & 7.5 & 8.7 & 6.0 & 3.5 & 2.5 \\
\hline Public external debt-GDP ratio (in percent) $1 /$ & 54.2 & 42.9 & 36.8 & 25.3 & 20.7 & 20.6 \\
\hline
\end{tabular}

Sources: Data provided by the Papua New Guinea authorities; and Fund staff estimates and projections. 1/ Public external debt includes central government, central bank external debt, and statutory authorities. 
Table 6. Papua New Guinea: Medium-Term Scenario, 2003-11

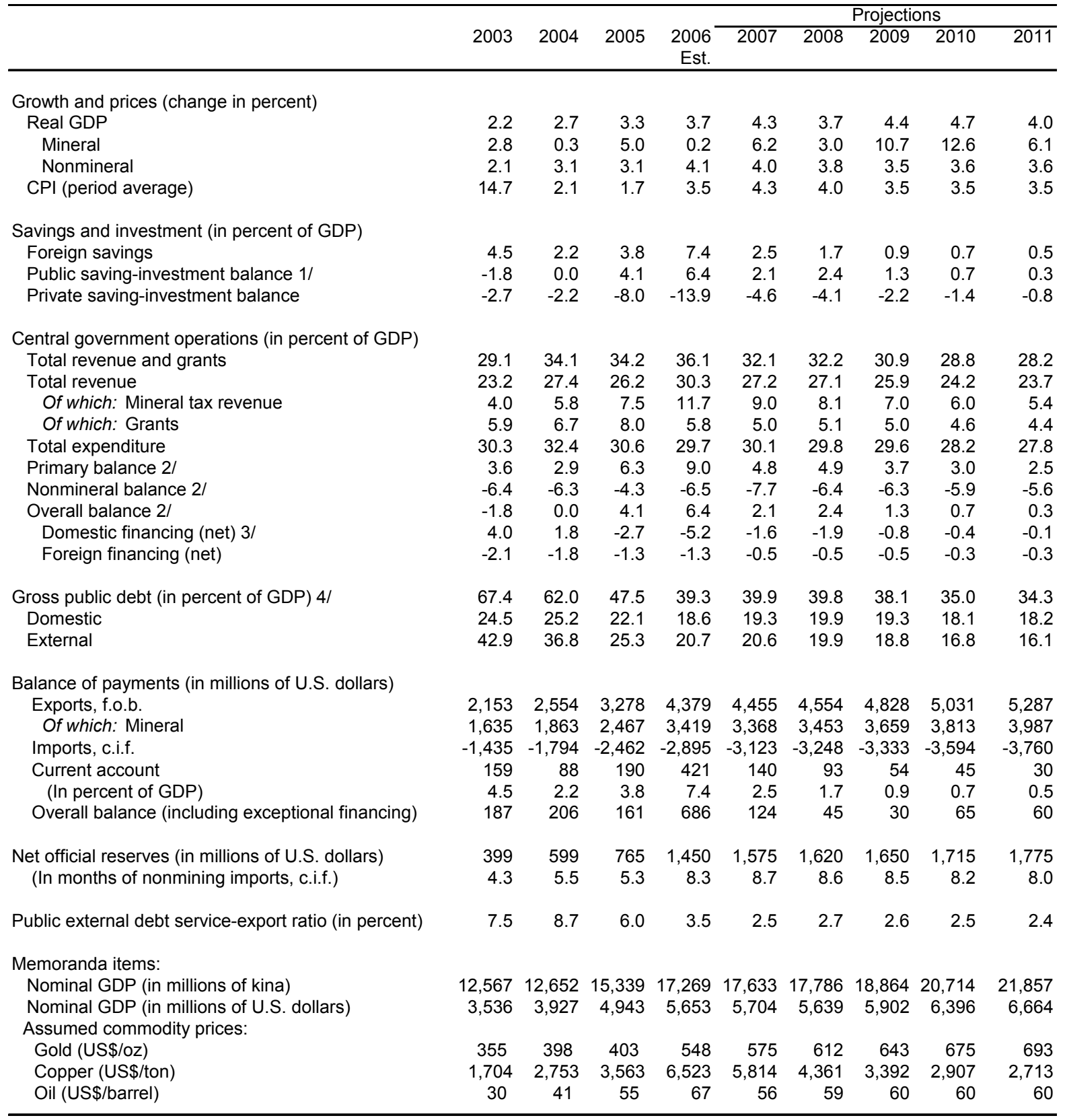

Sources: Department of Treasury; Bank of Papua New Guinea; and Fund staff estimates and projections.

1/ Central government operations only.

2/ Measured from below-the-line in the fiscal accounts.

$3 /$ Includes changes in check float.

4/ Includes central government, central bank external debt, and statutory authorities. 
Table 7. Papua New Guinea: Indicators of External Vulnerability, 2001-06

(In percent of GDP, unless otherwise indicated)

\begin{tabular}{|c|c|c|c|c|c|c|}
\hline & 2001 & 2002 & 2003 & 2004 & 2005 & $\begin{array}{c}2006 \\
\text { Est. }\end{array}$ \\
\hline \multicolumn{7}{|l|}{ Financial indicators } \\
\hline Gross pubic debt 1/ 2/ & 76.1 & 76.6 & 67.4 & 62.0 & 47.5 & 39.3 \\
\hline Broad money (percent change, 12-month basis) & 9.8 & 7.3 & -4.4 & 14.8 & 29.5 & 33.0 \\
\hline Private sector credit (percent change, 12 month basis) & 12.4 & 1.4 & -4.1 & 0.9 & 23.7 & 27.9 \\
\hline 182 day T-bill yield $1 /$ & 12.4 & 10.9 & 18.7 & 3.1 & 3.8 & 3.4 \\
\hline 182 day T-bill yield (real) $3 / 4 /$ & 1.8 & -3.4 & 9.5 & 0.7 & -0.7 & 0.9 \\
\hline \multicolumn{7}{|l|}{ External indicators } \\
\hline Exports (percent change, 12-month basis in U.S. dollars) & -15.2 & -12.4 & 30.8 & 18.6 & 28.4 & 33.6 \\
\hline Imports (percent change, 12-month basis in U.S. dollars) & -11.4 & -1.5 & 10.2 & 25.1 & 37.2 & 17.6 \\
\hline Current account balance & 6.5 & -1.0 & 4.5 & 2.2 & 3.8 & 7.4 \\
\hline Capital and financial account balance (millions of U.S. dollars) & -252.3 & -104.2 & -23.4 & 35.4 & -0.1 & 265.1 \\
\hline Of which: Inward foreign direct investment & 116.1 & 77.4 & 99.8 & 25.8 & 103.0 & 148.0 \\
\hline Gross official reserves (millions of U.S. dollars) & 439.7 & 339.0 & 523.0 & 663.1 & 764.9 & $1,450.8$ \\
\hline Central Bank short-term foreign liabilities (millions of U.S. dollars) & 1.2 & 1.0 & 4.0 & 0.4 & 0.4 & 0.4 \\
\hline Commerical bank foreign assets (millions of U.S. dollars) & 112.1 & 153.5 & 106.7 & 116.6 & 212.4 & 116.1 \\
\hline Commerical bank foreign liabilities (millions of U.S. dollars) & 13.9 & 26.0 & 16.9 & 21.9 & 31.0 & 27.0 \\
\hline Gross official reserves (months of nonmineral imports, c.i.f.) & 5.7 & 4.5 & 5.7 & 6.1 & 5.2 & 8.3 \\
\hline Broad money to gross reserves (ratio) & 2.0 & 2.6 & 2.0 & 1.9 & 2.1 & 1.5 \\
\hline Total short-term external debt to reserves (percent) $5 /$ & 3.2 & 7.7 & 3.2 & 3.3 & 4.1 & 1.9 \\
\hline Public external debt to GDP ratio (in percent) $2 /$ & 55.4 & 54.2 & 42.9 & 36.8 & 25.3 & 20.7 \\
\hline Public external debt service to exports (percent) & 7.9 & 7.9 & 7.5 & 8.7 & 6.0 & 3.5 \\
\hline Exchange rate (per U.S. dollar; period average) & 3.4 & 3.9 & 3.6 & 3.2 & 3.1 & 3.1 \\
\hline \multicolumn{7}{|l|}{ Financial market indicators } \\
\hline \multicolumn{7}{|l|}{ Foreign currency long-term government debt rating $1 /$} \\
\hline Moody's 6/ & B1(stab.) & B1(stab.) & B1(stab.) & B1(stab.) & B1(stab.) & $\mathrm{Ba} 2$ \\
\hline Standard \& Poors 7/ & B(stab.) & B(neg.) & B(stab.) & B(pos.) & B(pos.) & B \\
\hline
\end{tabular}

Sources: Department of Treasury; Bank of Papua New Guinea; and Fund staff estimates.

$1 /$ End of period.

2/ Includes central government, central bank external debt, and statutory authorities.

3/ Figures for 2006 are to date.

4/ Ex-post real rate.

5/ Covers only banking system short-term external debt.

6/ Initial rating of B1 (stable) in January 1999.

7/ Initial rating of B+ (stable) in January 1999. 


\section{Appendix I. Papua New Guinea: Public and External Debt Sustainability 5}

This appendix summarizes the debt sustainability analysis (DSA) for Papua New Guinea using the new framework for low-income countries. The baseline macroeconomic scenario underlying this DSA is the medium-term outlook discussed in the staff report, including the sustained implementation of the ongoing medium-term fiscal strategy. This appendix also assesses the impact of various exogenous shocks on the sustainability of public sector debt and external debt under the baseline scenario.

\section{A. Main Assumptions}

- $\quad$ Real GDP growth is projected to grow at about 4 percent in 2006-2011 as agricultural productivity improves, several mining projects come on stream, and continued gradual progress is made on structural reform.

- $\quad$ Monetary policy continues to be geared toward maintaining low inflation and achieving a sound external position.

- $\quad$ Fiscal policy remains unchanged and in line with the government's medium-term fiscal strategy; surpluses are expected to decline due to falling mineral revenues and nonmineral balances improve steadily after 2007.

- $\quad$ Papua New Guinea would have access to external concessional finance and continue to follow a prudent debt strategy.

- $\quad$ Prices of key commodities are in line with January 2007 WEO assumptions.

- $\quad$ Structural reforms outlined under the authorities' Medium-term Development Strategy, including those on public sector reform, are implemented at a gradual pace.

- Given the considerable uncertainty surrounding the PNG-Queensland gas pipeline project, this DSA assumes no government borrowing to finance an equity participation (in contrast to that envisaged in the 2005 Article IV DSA).

\footnotetext{
${ }^{5}$ As Papua New Guinea is an IBRD/IDA blend country, this DSA was prepared by Fund staff only under the IMF-WB DSA framework for Low-Income Countries. See Operational Framework for Debt Sustainability Assessments in Low-Income Countries-Further Considerations.
} 


\section{B. Total Public Sector Debt Sustainability}

The public sector debt ratio declined from 67.4 percent of GDP at end-2003 to an estimated 39.3 percent of GDP at end-2006 (Appendix I, Table 1). This improvement reflects prudent fiscal policy, favorable mineral sector developments (in particular, strong export prices in recent years), kina appreciation, lower interest rates, and a sustained recovery since the current government took office in mid-2002. Of total public debt, approximately 50 percent is external debt, of which 47 percent of loans are in US dollars, 36 percent in Japanese yen, and 14 percent in Euros. Multilateral debt accounts for about twothirds (AsDB and World Bank) of external debt. Japan is the main bilateral creditor. Under the authorities' Medium-Term Debt Strategy, foreign-currency loans are considered only if they are highly concessionary (grant element of 35 percent).

Under the baseline, the public sector debt ratio is projected to decline to 34.3 percent of GDP by 2011 and 13.6 percent by 2026 . The projected debt improvement stems mainly from the expectation of a continued prudent fiscal policy into the medium term, and favorable debt dynamics. The NPV of public debt would decline sharply from 48.2 percent of GDP in 2005 to 40.1 percent of GDP in 2006, and continue to decline to 35.3 percent of GDP by 2011 and to 13.5 percent of GDP by 2026. The NPV of public debt service-torevenue ratio, which is estimated to fall significantly in 2006 due to high windfall revenue, is expected to rise somewhat in 2007 as mineral revenue moderates. The debt service to revenue ratio should revert to being relatively stable (13 percent), before declining sharply in the longer term.

\section{Papua New Guinea faces a moderate risk of debt distress under the IMF-WB DSA} framework for LICs. ${ }^{6}$ The main results are: (i) only one indicator-NPV of debt to GDP ratio - is above its threshold under the baseline scenario - and it declines under the threshold over the long term, (ii) other indicators are well below their thresholds over the entire projected period, and (iii) only under one bound test for lower real GDP growth are these thresholds significantly breached.

\section{The standard analysis indicates that the paths of the debt ratios are particularly} sensitive to changes in real GDP growth and the exchange rate (Appendix I, Table 2 and Figure 1). Compared to 2006, a decline in real GDP growth to one standard deviation below its historical average would raise the NPV of public debt to GDP ratio by about 20 percentage points of GDP in the long term. A one-time 30 percent real exchange rate

\footnotetext{
${ }^{6}$ Papua New Guinea is rated a poor performer for its policies and institutions by the IMF-WB LIC DSA framework. Thus, Papua New Guinea's applicable thresholds are: (i) 100 percent for NPV of debt-to-exports, (ii) 30 percent for NPV of debt-to-GDP, and (iii) 200 percent for NPV of debt-to-fiscal revenue; and for debt service: (i) 15 percent of exports and (ii) 25 percent of revenues.
} 
depreciation in 2007 would raise the NPV of debt to GDP ratio by about 10 percentage points.

\section{External Debt Sustainability}

Papua New Guinea's total external debt has declined in recent years, from 65.3 percent of GDP in 2003 to 32.9 percent in 2006 (Appendix I, Table 3). External debt as a percent of exports is also estimated to have declined significantly from 107 percent in 2003 to 42 percent in 2006.

External public debt dynamics are sustainable under the baseline scenario, as all three debt indicators (the NPV of public external debt of GDP, the NPV of debt in percent of exports, and the debt service to exports ratio) do not breach the key thresholds. Based on available data, private external debt was estimated at 12 percent of GDP at end-2006. Private external debt is expected to decline over the long term, as large mineral projects that accounted for a high proportion of debt reach completion.

External debt sustainability is most vulnerable to shocks to lower export growth. Stress tests were carried out to test the robustness of the baseline scenario. The decline in export value growth by one standard deviation below its historical average would raise the NPV of public external debt-to-GDP threshold by 25 percentage points during 2006-09, and only fall below the threshold level in 2019. A one time 30 percent nominal depreciation in 2007 would raise the NPV of debt to GDP by 6 percentage points in the first three years before falling over the longer term. The export shock to the NPV of debt-to-exports would raise the level closer to (though still under) the distress threshold for the first ten years, before falling over the long term. Papua New Guinea's external debt distress risk is further moderated by the fact that it has an excellent external repayment record, having never defaulted in the past.

\section{Conclusions}

While Papua New Guinea has made significant progress in reducing its public debt burden, it will need to continue its prudent management of debt over the medium-tolong term in order to mitigate risks to public debt sustainability. While most indicators show that the economy's debt is manageable, Papua New Guinea faces a moderate risk of debt distress. The outlook is particularly sensitive to changes in real GDP growth and to the exchange rate, highlighting the vulnerability of the debt dynamics to potential shocks and the need to avoid policy slippages. To further help guard against these vulnerabilities, Papua New Guinea should ensure that any external borrowing is obtained on concessional terms, in line with its Medium-Term Debt Strategy. 
Appendix I. Figure 1. Papua New Guinea: Indicators of Public Debt Under Alternative Scenarios, 2006-2026 1/
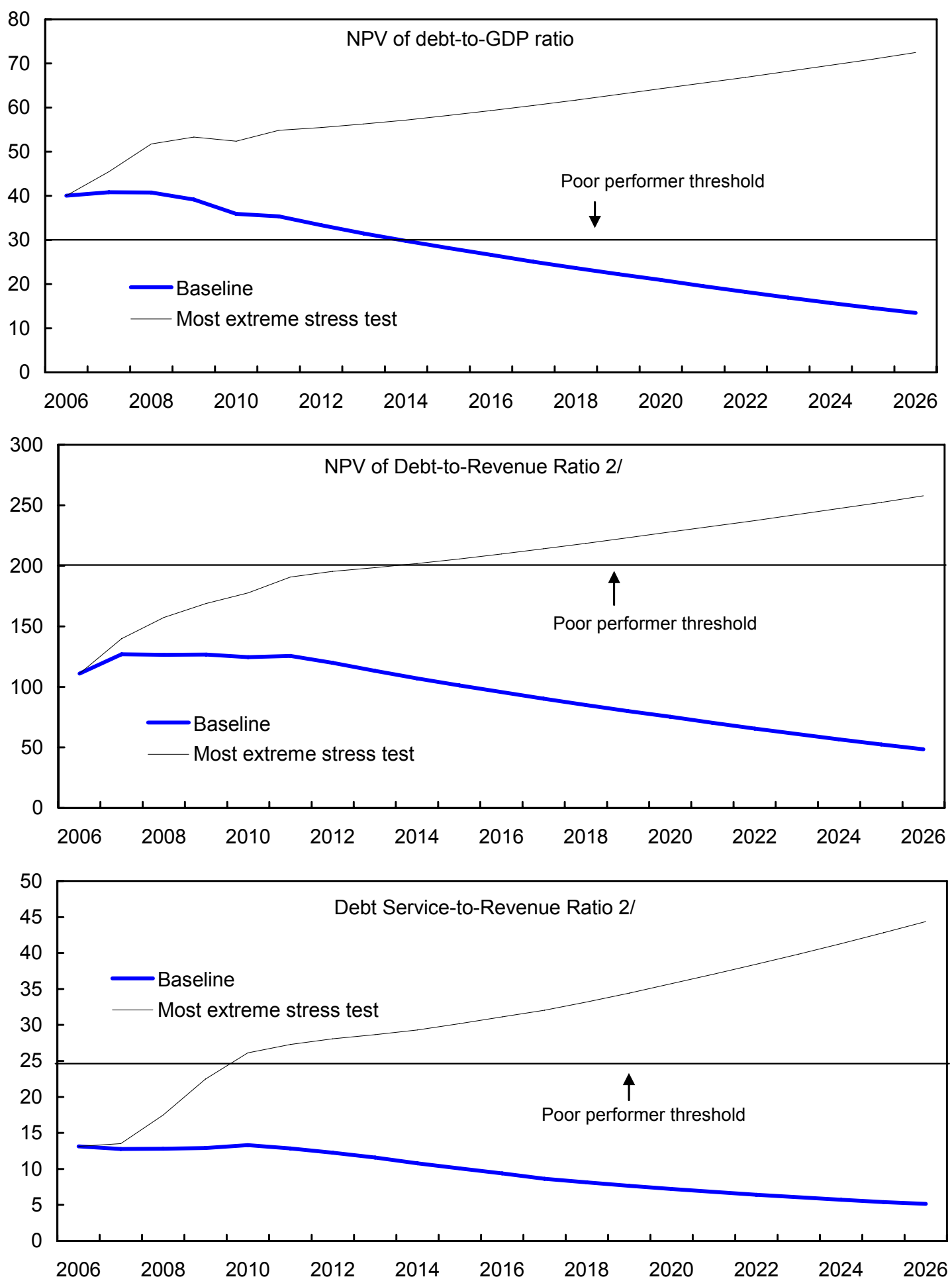

Sources: Papua New Guinea authorities; and Fund staff projections and simulations.

$1 /$ Most extreme stress test is test that yields highest ratio in 2016.

2/ Revenue including grants. 
Appendix I. Figure 2. Papua New Guinea: Indicators of Public and Publicly Guaranteed External Debt Under Alternative Scenarios, 2006-2026

(In percent)
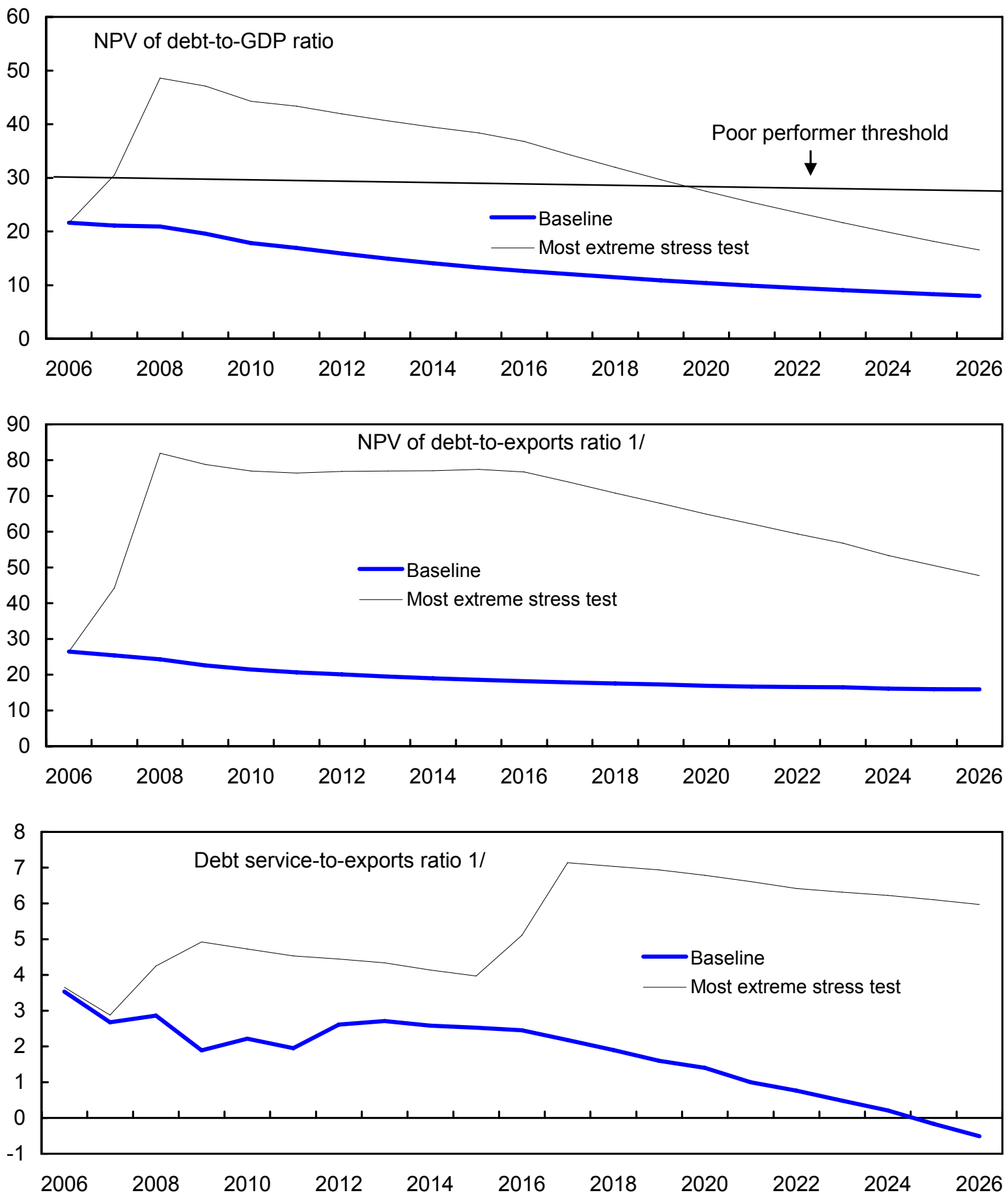

Sources: Papua New Guinea authorities; and Fund staff projections and simulations.

1/ Poor performer threshold for NPV of debt-to-exports ratio is 100 percent and for debt service-to-exports ratio is 15 percent. 


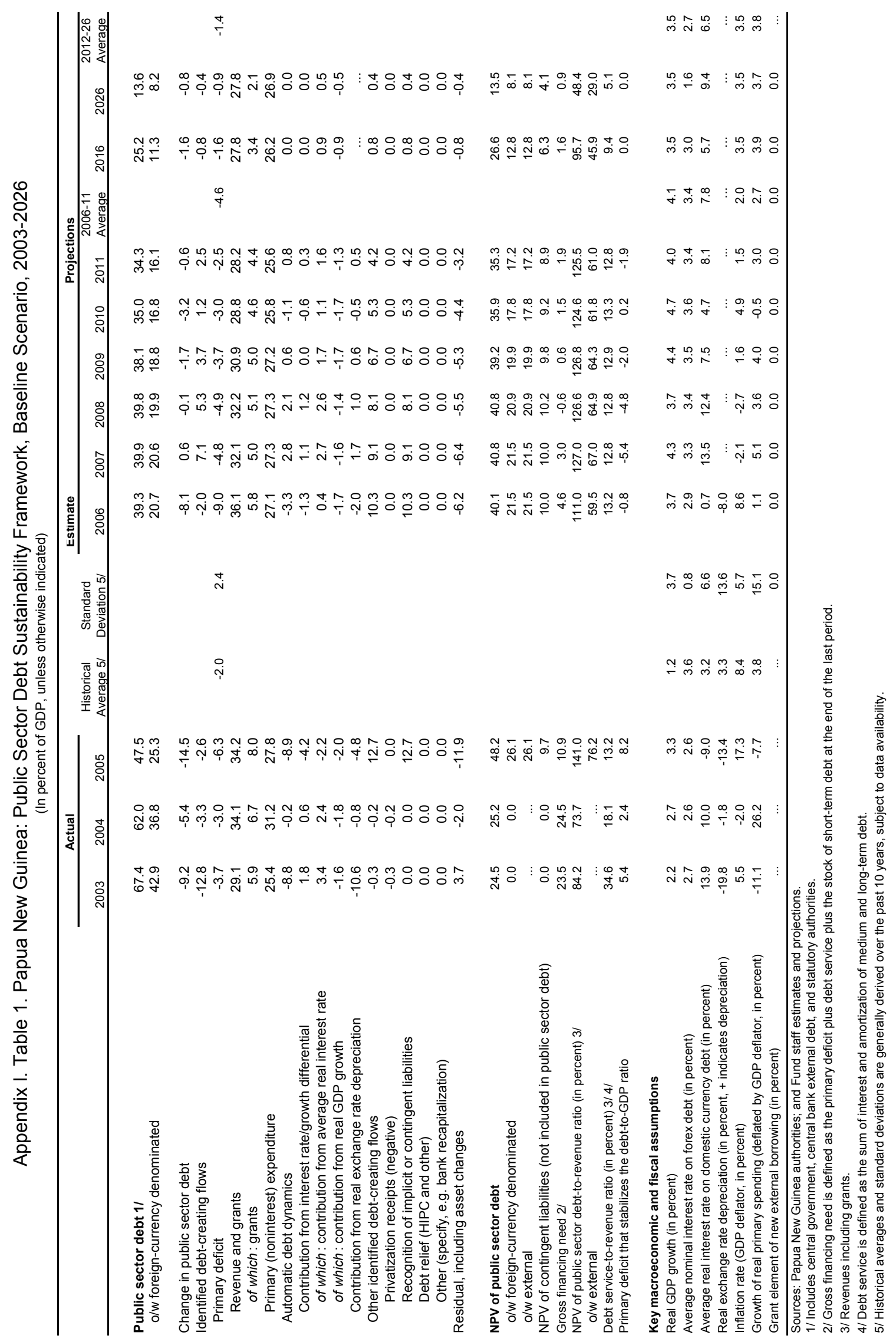


Appendix I. Table 2. Papua New Guinea: Sensitivity Analysis for Key Indicators of Public Debt 2006-2026

NPV of Debt-to-GDP Ratio
Baseline
A. Alternative scenarios
A1. Real GDP growth and primary balance are at historical averages
A2. Primary balance is unchanged from 2006
A3. Permanently lower GDP growth $1 /$
B. Bound tests
B1. Real GDP growth is at historical average minus one standard deviations in 2007-2008
B2. Primary balance is at historical average minus one standard deviations in 2007-2008
B3. Combination of B1-B2 using one half standard deviation shocks
B4. One-time 30 percent real depreciation in 2007
B5. 10 percent of GDP increase in other debt-creating flows in 2007

\section{NPV of Debt-to-Revenue Ratio 2}

\section{Baseline}

\section{A. Alternative scenarios}

A1. Real GDP growth and primary balance are at historical averages A2. Primary balance is unchanged from 2006

A3. Permanently lower GDP growth $1 /$

\section{B. Bound tests}

B1. Real GDP growth is at historical average minus one standard deviations in 2007-2008 B2. Primary balance is at historical average minus one standard deviations in 2007-2008 B3. Combination of B1-B2 using one half standard deviation shocks

B4. One-time 30 percent real depreciation in 2007

B5. 10 percent of GDP increase in other debt-creating flows in 2007

Debt Service-to-Revenue Ratio 2/

\section{Baseline}

\section{A. Alternative scenarios}

A1. Real GDP growth and primary balance are at historical averages

A2. Primary balance is unchanged from 2006

A3. Permanently lower GDP growth $1 /$

\section{B. Bound tests}

B1. Real GDP growth is at historical average minus one standard deviations in 2007-2008 B2. Primary balance is at historical average minus one standard deviations in 2007-2008

B3. Combination of B1-B2 using one half standard deviation shocks

B4. One-time 30 percent real depreciation in 2007

B5. 10 percent of GDP increase in other debt-creating flows in 2007

$\begin{array}{rrrrrrrr}40 & 41 & 41 & 39 & 36 & 35 & 27 & 13 \\ & & & & & & & \\ 40 & 45 & 49 & 51 & 50 & 51 & 47 & 34 \\ 40 & 37 & 33 & 26 & 18 & 11 & -29 & -106 \\ 40 & 41 & 42 & 41 & 39 & 40 & 39 & 57\end{array}$

$\begin{array}{llllllll}40 & 45 & 52 & 53 & 52 & 55 & 59 & 72 \\ 40 & 46 & 51 & 49 & 45 & 45 & 36 & 22 \\ 40 & 47 & 53 & 51 & 47 & 47 & 36 & 19 \\ 40 & 51 & 52 & 50 & 46 & 45 & 36 & 20 \\ 40 & 50 & 50 & 49 & 45 & 45 & 35 & 21\end{array}$

$\begin{array}{llllllll}111 & 127 & 127 & 127 & 125 & 126 & 96 & 48\end{array}$

$\begin{array}{rrrrrrrr}111 & 139 & 151 & 162 & 169 & 178 & 164 & 116 \\ 111 & 115 & 102 & 85 & 63 & 40 & -104 & -383\end{array}$

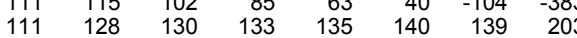

$\begin{array}{lrrrrrrr}111 & 140 & 157 & 169 & 178 & 191 & 210 & 258 \\ 111 & 142 & 158 & 159 & 158 & 160 & 129 & 78 \\ 111 & 145 & 163 & 164 & 161 & 163 & 127 & 69 \\ 111 & 160 & 160 & 162 & 160 & 162 & 128 & 71 \\ 111 & 156 & 156 & 158 & 156 & 158 & 127 & 77\end{array}$

$\begin{array}{llllllll}13 & 13 & 13 & 13 & 13 & 13 & 9 & 5\end{array}$

$\begin{array}{rrrrrrrr}13 & 13 & 18 & 22 & 24 & 23 & 19 & 15 \\ 13 & 13 & 6 & 2 & -3 & -8 & -32 & -77 \\ 13 & 13 & 13 & 14 & 15 & 16 & 18 & 35\end{array}$

Sources: Papua New Guinea authorities; and Fund staff projections and simulations.

1/ Assumes that real GDP growth is at baseline minus one standard deviation divided by the square root of 20 (i.e., the length of the projection period).

2/ Revenues are defined inclusive of grants. 


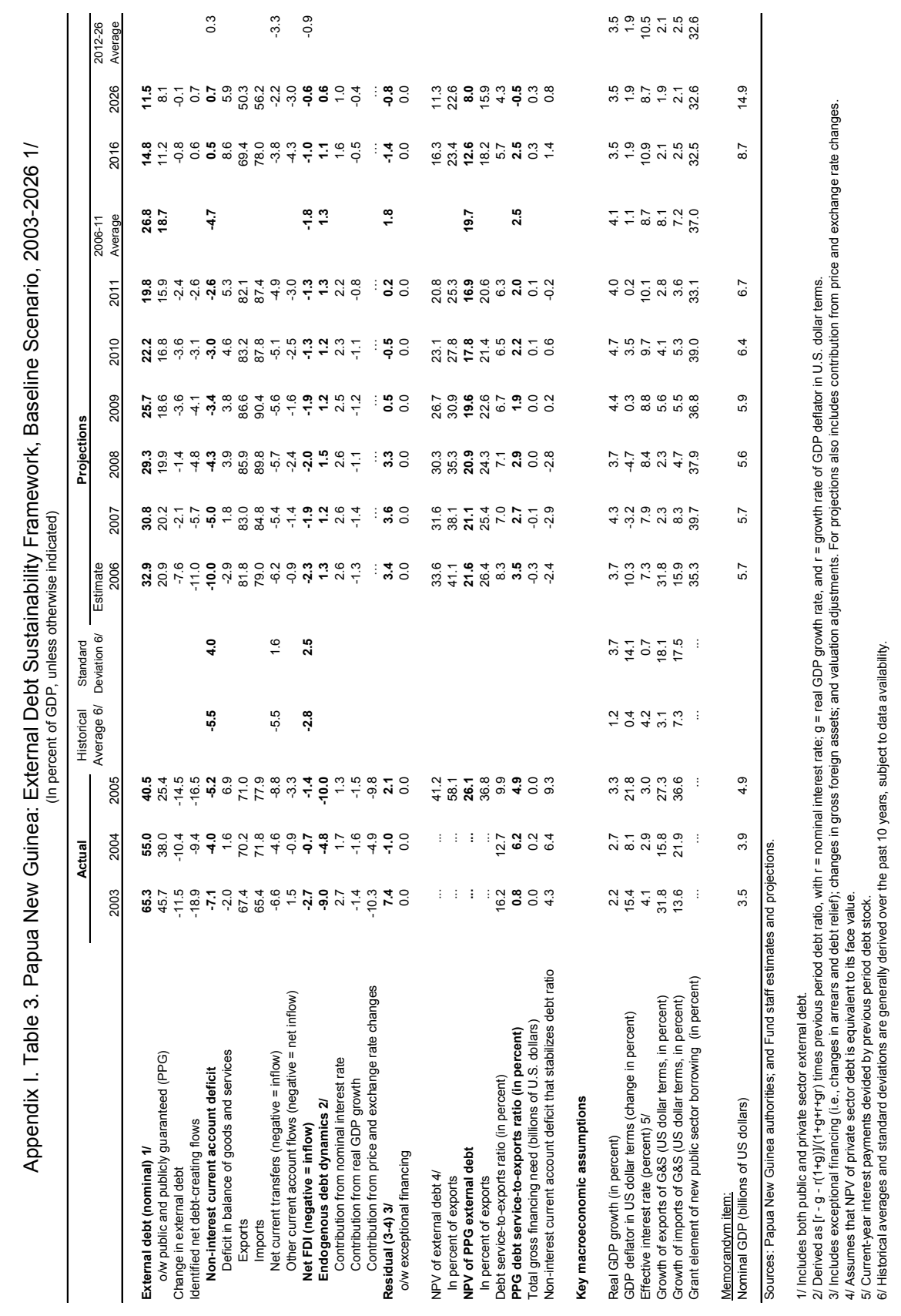


Appendix I. Table 4. Papua New Guinea: Sensitivity Analyses for Key Indicators of Public and Publicly Guaranteed External Debt, 2006-26 (In percent)

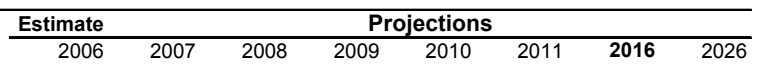

NPV of debt-to-GDP ratio

Baseline

$\begin{array}{ll}22 & 21 \\ 22 & 20 \\ 22 & 21 \\ & \\ 22 & 23 \\ 22 & 31 \\ 22 & 24 \\ 22 & 23 \\ 22 & 29 \\ 22 & 31\end{array}$

A. Alternative Scenarios

A1. Key variables at their historical averages in 2007-26 1/

A2. New public sector loans on less favorable terms in 2007-26 2

B. Bound Tests

B1. Real GDP growth at historical average minus one standard deviation in 2007-08

B2. Export value growth at historical average minus one standard deviation in 2007-08 3 /

B3. US dollar GDP deflator at historical average minus one standard deviation in 2007-08

B4. Net non-debt creating flows at historical average minus one standard deviation in 2007-08

B5. Combination of B1-B4 using one-half standard deviation shocks

B6. One-time 30 percent nominal depreciation relative to the baseline in 20075 /

NPV of debt-to-exports ratio

Baseline

$\begin{array}{rrrrrrrr}26 & 25 & 24 & 23 & 21 & 21 & \mathbf{1 8} & 16 \\ & & & & & & & \\ 26 & 24 & 20 & 17 & 13 & 9 & \mathbf{- 2 8} & -146 \\ 26 & 26 & 25 & 24 & 23 & 22 & \mathbf{2 2} & 23 \\ & & & & & & & \\ & & & & & & & \\ 26 & 25 & 24 & 23 & 21 & 21 & \mathbf{1 8} & 16 \\ 26 & 44 & 82 & 79 & 77 & 76 & \mathbf{7 7} & 48 \\ 26 & 25 & 24 & 23 & 21 & 21 & \mathbf{1 8} & 16 \\ 26 & 28 & 30 & 28 & 27 & 26 & \mathbf{2 4} & 19 \\ 26 & 35 & 50 & 48 & 47 & 46 & \mathbf{4 5} & 30 \\ 26 & 25 & 24 & 23 & 21 & 21 & \mathbf{1 8} & 16\end{array}$

A. Alternative Scenarios

A1. Key variables at their historical averages in 2007-26 1

A2. New public sector loans on less favorable terms in 2007-26 2/

Debt service ratio

Baseline

A. Alternative Scenarios

A1. Key variables at their historical averages in 2007-26 1/

A2. New public sector loans on less favorable terms in 2007-26 2/

\section{B. Bound Tests}

B1. Real GDP growth at historical average minus one standard deviation in 2007-08

B2. Export value growth at historical average minus one standard deviation in 2007-08 3/

B3. US dollar GDP deflator at historical average minus one standard deviation in 2007-08

B4. Net non-debt creating flows at historical average minus one standard deviation in 2007-08

B5. Combination of B1-B4 using one-half standard deviation shocks

B6. One-time 30 percent nominal depreciation relative to the baseline in $20075 /$

Memorandum item:

Grant element assumed on residual financing (i.e., financing required above baseline) $6 /$

4

3

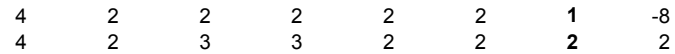

Sources: Papua New Guinea authorities; and Fund staff projections and simulations.

1/ Variables include real GDP growth, growth of GDP deflator (in U.S. dollar terms), non-interest current account in percent of GDP, and non-debt creating flows.

2/ Assumes that the interest rate on new borrowing is by 2 percentage points higher than in the baseline., while grace and maturity periods are the same as in the baseline.

3/ Exports values are assumed to remain permanently at the lower level, but the current account as a share of GDP is assumed to return to its baseline level after the shock (in an offsetting adjustment in import levels).

4/ Includes official and private transfers and FDI.

5/ Depreciation is defined as percentage decline in dollar/local currency rate, such that it never exceeds 100 percent.

6/ Applies to all stress scenarios except for A2 (less favorable financing) in which the terms on all new financing are as specified in footnote 2. 


\section{Appendix III. Papua New Guinea: Summary OF AnNexes}

\section{Fund Relations}

Papua New Guinea joined the Fund in October 1975, and has no outstanding purchases or loans. The last stand-by arrangement expired in September 2001. Papua New Guinea has a managed floating exchange rate arrangement; the exchange rate of the kina is determined in the interbank market in which authorized banks participate. The 2005 Article IV consultation was concluded by the Executive Board on February 13, 2006 (IMF Country Report No. 06/99).

\section{Relations with the World Bank Group}

Papua New Guinea has received 35 IBRD loans and 13 IDA credits amounting to \$787 million and \$115 million in commitments, respectively. At present, there are two active loans, totaling \$65 million. In June 2003, the Bank suspended disbursements on the Forestry and Conservation Project due to noncompliance with the loan agreement. The loan was cancelled at the government's request in June 2005. The Bank is involved in public expenditure management, health and education, and HIV/AIDS. An Interim Strategy Note provided guidance through end-2006 and a Country Assistance Strategy is now under preparation. The IFC has committed $\$ 14.5$ million.

\section{Relations with PFTAC}

Assistance to Papua New Guinea in recent years has been limited due to the presence of extensive assistance under the Australian Enhanced Cooperation Program (ECP). In all, there have been 21 missions since 2000, and Papua New Guinea has sent over 50 officials to the Center's regional seminars, workshops and training courses in this period.

\section{Relations with the Asian Development Bank}

Papua New Guinea has been approved 59 loans totaling $\$ 927$ million for 46 projects. Currently there are 9 active loan-financed projects (and one special fund grant-financed project). AsDB approved a new strategy in July 2006 focusing on (i) public finance management; (ii) private sector development; (iii) transport sector; and (iv) health and HIV/AIDS. Public enterprises and utilities reform are key issues the AsDB will support, initially through technical assistance. Total lending over 2006-2008 is expected to remain a blend of Asian Development Fund (\$77 million) and ordinary capital resources. Lending will include one new priority investment project per year. 


\section{Statistical Issues}

Although data provision to the Fund is generally adequate for surveillance purposes, inadequate coverage and timeliness of key macroeconomic data continue to hinder the conduct of macroeconomic policy. The September 2006 STA multisector statistics mission assessed the institutional arrangements, methodological foundations, and accuracy and reliability of data and found serious shortcomings. 


\section{INTERNATIONAL MONETARY FUND}

Public Information Notice (PIN) No. 07/36

FOR IMMEDIATE RELEASE

March 21, 2007
International Monetary Fund $70019^{\text {th }}$ Street, NW

Washington, D. C. 20431 USA

\section{IMF Executive Board Concludes 2006 Article IV Consultation with Papua New Guinea}

On March 7, 2007, the Executive Board of the International Monetary Fund (IMF) concluded the Article IV consultation with Papua New Guinea. ${ }^{1}$

\section{Background}

Papua New Guinea is enjoying its fourth year of recovery and macroeconomic stability, but major challenges lie ahead. Sound macroeconomic policies over the past several years have reduced fiscal vulnerabilities, lowered inflation, spurred business confidence, and boosted growth. High prices for key export commodities (petroleum, copper, gold, and most agricultural products) have strengthened the fiscal and external positions. However, progress toward achieving the country's Medium-Term Development Strategy objectives or Millennium Development Goals has been limited. In particular, structural reforms needed to stimulate activity in the nonmineral economy have stalled in advance of the June 2007 general elections.

Reflecting past years of political instability and weak economic management, per capita income is little improved since independence in 1975. As a result of earlier election-year fiscal policy excesses, the current government faced a near crisis situation when it took office in 2002; its efforts during its initial years mainly—and successfully—focused on

\footnotetext{
${ }^{1}$ Under Article IV of the IMF's Articles of Agreement, the IMF holds bilateral discussions with members, usually every year. A staff team visits the country, collects economic and financial information, and discusses with officials the country's economic developments and policies. On return to headquarters, the staff prepares a report, which forms the basis for discussion by the Executive Board. At the conclusion of the discussion, the Managing Director, as Chairman of the Board, summarizes the views of Executive Directors, and this summary is transmitted to the country's authorities.
} 
stabilizing the fiscal situation and promoting economic recovery. However, underlying development needs in Papua New Guinea still remain to be fully addressed. The dominance of the natural resource sector has hindered the development of nonmineral sectors of the economy. Poor infrastructure, weak governance, and an unattractive business environment have constrained more rapid growth. Although recent growth rates have been strong relative to the past, the growth performance gap relative to comparator countries is widening. Poverty and unemployment remain high as the economy is unable to absorb a rapidly growing labor force.

Recent developments and the near-term outlook remain favorable. High commodity prices and expanding mineral production should contribute to continued growth and large fiscal and external surpluses. The recovery is expected to gain steam in 2007, with growth rising to over 4 percent, as new mines begin production and increased government spending stimulates activity in the nonmineral sector. Inflation is expected to rise slightly, as fiscal spending increases pressure on prices, but remain within the low single digits.

The current account surplus should narrow in 2007 as the value of mineral exports begins to decline with lower prices expected for key exports. Official external reserves should increase to about $\$ 1.6$ billion (4 months of goods and services imports). After a steep rise in the kina's value in 2003-05, it appreciated by 3 percent against the U.S. dollar and 6 percent on a real effective basis in 2006.

An overall fiscal surplus is expected for the third successive year in 2007, although the underlying nonmineral deficit would further widen due to higher spending and lower nonmineral tax revenue. The 2006-07 budgets provide for large spending increases mainly for development expenditure (over three quarters of the total increase), much of it one-off, and smaller allotments for public enterprise investment, natural disaster victims, and domestic arrears clearance. Given weak implementation capacity and the late timing of the 2006 supplementary budgets, it is estimated that a limited amount of the expenditure appropriations was spent in 2006, and the remainder deposited in trust fund accounts for future spending. Repayment of 0.5 percent of GDP of external debt in 2006 combined with positive debt dynamics (real GDP growth, kina appreciation, and low interest rates) should contribute to a public sector debt-to-GDP ratio of 40 percent in 2007.

The macroeconomic outlook should remain positive, if fiscal and monetary policies are maintained on their current path. Real GDP growth of about 4 percent is expected over the medium term, together with continued low inflation rates. Falling export prices should underlie narrowing external current account surpluses. The nonmineral fiscal deficit is expected to improve gradually after 2007, if one-off spending in the 2006-07 budgets is not carried over, and the "right sizing" program to streamline the government is implemented. 
However, the balance of risks is to the downside. Higher-than-expected election-related spending could lead to increasing price pressure; the resulting rise in interest rates as monetary policy is tightened could choke off economic growth. Still weak fiscal accountability, especially for many trust funds, also poses risks of higher or inefficient spending. A steeper-than-anticipated decline in world export commodity prices or postponement of large mineral projects would heighten the need for fiscal adjustment to allow room for essential development spending. Inaction or unwinding of previous progress on structural reform would dampen investor confidence. The further spread of HIVIAIDs would have consequences for growth and human development. On the upside, rapid development of gas reserves could improve the longer-term outlook for growth.

A doubling of the baseline growth rates would be needed to significantly reduce poverty and unemployment. Stronger annual growth of 7-8 percent is within reach, but would require more effective use of Papua New Guinea's mineral wealth, including a sustainable medium-term fiscal policy that efficiently delivers needed development expenditure, and decisive efforts on structural reform to encourage greater activity in the nonmineral sector. The resulting strengthened fiscal position would improve the debt sustainability outlook.

\section{Executive Board Assessment}

The Directors commended the Papua New Guinea authorities for their sound and supportive macroeconomic policies. Along with favorable commodity export prices, these have led to a sustained economic recovery, macroeconomic stability, a strong external position, and a declining debt-to-GDP ratio in recent years. However, Directors recognized that significant challenges remain, including the need to reduce unemployment and poverty and the economy's vulnerability to external shocks. They encouraged the authorities to maintain prudent macroeconomic policies and to step up the pace of structural reform, in order to accelerate economic diversification, boost private investment and growth, and move more quickly toward the Millennium Development Goals.

Directors welcomed the central bank's focus on price stability and its readiness to tighten monetary policy should inflation pressures emerge. Directors considered the managed float of the exchange rate to be an appropriate response to appreciation pressures stemming from the temporary influx of mineral export revenues. While recognizing the importance of maintaining the competitiveness of the non-mineral sector, they advised that the potential inflationary pressures from increased liquidity be carefully monitored, and that, in the event of sustained revenue inflows, a more flexible exchange rate would help contain such pressures.

Directors welcomed the shift of emphasis from recurrent to development spending, particularly for infrastructure and human capital, in the 2006 supplementary budgets and the 2007 budget. At the same time, they expressed some concern about the potential 
size of the spending increases and the risk that spending might not always be used as appropriated, given the weak budget implementation capacity, the approach of the mid-2007 parliamentary elections, and the economy's limited absorptive capacity. In this regard, Directors were encouraged by the authorities' commitment to maintain fiscal prudence in the run-up to the elections. They encouraged strengthened public expenditure management, subjection of all major spending agencies to basic accountability procedures, pressing ahead with the closure of unneeded trust accounts, and a resumption of the "right-sizing" initiative to streamline government spending.

Directors emphasized the importance of preserving the non-mineral revenue base and containing the non-mineral fiscal deficit to maintain long-term fiscal sustainability. They supported plans to improve tax administration, and welcomed the progress made in implementing the government's medium-term debt strategy. Looking ahead, Directors saw merit in continuing to cautiously spend any mineral revenue windfalls in future years for priority infrastructure and projects that enhance social welfare, to the extent that absorptive capacity permits, and to use the remainder to further reduce debt as much as possible.

Directors welcomed the overall soundness of the financial system. They viewed the recent expansion of bank credit to the private sector as a sign of re-intermediation and business confidence, while cautioning that credit quality should be monitored closely. They encouraged the authorities to further strengthen supervision, particularly of non-banks, and to implement the recently-passed legislation against money laundering and terrorism financing. Directors expressed concern that the Rural Development Bank's planned expansion into microfinance operations would lack adequate prudential oversight.

While appreciating the institutional constraints facing Papua New Guinea, Directors stressed that greater progress is needed in removing the structural impediments to private sector activity and more rapid growth. They highlighted, in particular, the importance of improving the business environment, the governance and law enforcement systems, and the transport and communications infrastructure. As basic utility services remain costly and unreliable, Directors recommended that the necessary regulatory framework be quickly finalized as a first step toward introducing competition in the public enterprise sector. Beyond this, the authorities were also encouraged to reconsider their decision not to move forward on privatization.

Directors recommended that a stronger effort be made to improve the quality and timelines of macroeconomic statistics. 
Public Information Notices (PINs) form part of the IMF's efforts to promote transparency of the IMF's views and analysis of economic developments and policies. With the consent of the country (or countries) concerned, PINs are issued after Executive Board discussions of Article IV consultations with member countries, of its surveillance of developments at the regional level, of post-program monitoring, and of ex post assessments of member countries with longer-term program engagements. PINs are also issued after Executive Board discussions of general policy matters, unless otherwise decided by the Executive Board in a particular case. 
Papua New Guinea: Selected Economic Indicators, 2002-06

\begin{tabular}{|c|c|c|c|c|c|}
\hline & 2002 & 2003 & 2004 & 2005 & $\frac{2006}{\text { Est. }}$ \\
\hline \multicolumn{6}{|l|}{ Real sector (percent change) } \\
\hline Real GDP growth & -0.2 & 2.2 & 2.7 & 3.3 & 3.7 \\
\hline Mineral & -15.9 & 2.8 & 0.3 & 5.0 & 0.2 \\
\hline Nonmineral & 2.5 & 2.1 & 3.1 & 3.1 & 4.1 \\
\hline CPI (annual average) & 11.8 & 14.7 & 2.1 & 1.7 & 3.5 \\
\hline \multicolumn{6}{|l|}{ Central government budget (percent of GDP) } \\
\hline Revenue and grants & 27.8 & 29.1 & 34.1 & 34.2 & 36.1 \\
\hline Expenditure and net lending & 31.9 & 30.3 & 32.4 & 30.6 & 29.7 \\
\hline Overall balance, cash basis (including grants) 1/ & -5.3 & -1.8 & 0.0 & 4.1 & 6.4 \\
\hline Domestic financing (net) 2/ & 6.1 & 4.0 & 1.8 & -2.7 & -5.2 \\
\hline Of which: Banking system & 6.3 & -0.9 & 0.3 & -1.2 & -2.4 \\
\hline External financing (net) & -0.9 & -2.1 & -1.8 & -1.4 & -1.3 \\
\hline \multicolumn{6}{|l|}{ Money and credit (end-period percentage change) } \\
\hline Domestic credit & 30.7 & -7.1 & 1.5 & 8.6 & 5.4 \\
\hline Net credit to government & 114.4 & -8.3 & 3.2 & -13.9 & -37.3 \\
\hline Credit to the private sector & 1.4 & -4.1 & 0.9 & 23.7 & 27.9 \\
\hline Broad money & 7.3 & -4.4 & 14.8 & 29.5 & 33.0 \\
\hline Interest rate (182-day T-bills, period average) & 10.9 & 18.7 & 3.1 & 3.8 & 3.4 \\
\hline \multicolumn{6}{|l|}{ Balance of payments (in millions of U.S. dollars) } \\
\hline Exports, f.o.b. & 1,646 & 2,153 & 2,554 & 3,278 & 4.379 \\
\hline Imports, c.i.f. & $-1,302$ & $-1,435$ & $-1,794$ & $-2,462$ & $-2,895$ \\
\hline Current account (including grants) & -31 & 159 & 88 & 190 & 421 \\
\hline (In percent of GDP) & -1.0 & 4.5 & 2.2 & 3.8 & 7.4 \\
\hline Overall balance & -101 & 187 & 206 & 161 & 686 \\
\hline \multicolumn{6}{|c|}{ Reserves and external debt (end-period, in millions of U.S. dollars) } \\
\hline Net international reserves & 223 & 399 & 599 & 765 & 1,450 \\
\hline (In months of nonmining imports, c.i.f.) & 3.0 & 4.3 & 5.5 & 5.2 & 8.3 \\
\hline Gross international reserves & 339 & 523 & 663 & 765 & 1,451 \\
\hline (In months of nonmining imports, c.i.f.) & 4.5 & 5.7 & 6.1 & 5.2 & 8.3 \\
\hline Public external debt-to-GDP ratio (in percent) 3/ & 54.2 & 42.9 & 36.8 & 25.3 & 20.7 \\
\hline Public external debt-service ratio (percent of GNFS) & 7.9 & 7.5 & 8.7 & 6.0 & 3.5 \\
\hline \multicolumn{6}{|l|}{ Exchange and interest rates } \\
\hline US\$/kina (period average) & 0.2573 & 0.2814 & 0.3104 & 0.3223 & 0.3274 \\
\hline US\$/kina (end-period) & 0.2488 & 0.3000 & 0.3200 & 0.3230 & 0.3300 \\
\hline Nominal GDP (millions of kina) & 11,656 & 12,567 & 12,652 & 15,339 & 17,269 \\
\hline
\end{tabular}

Sources: Data provided by the Papua New Guinea authorities; and IMF staff estimates.

1/ Measured from below the line in the fiscal accounts.

$2 /$ Includes changes in check float.

$3 /$ Includes central government, central bank external debt, and statutory authorities. 